Bond University

Research Repository

\title{
Bonverstr
}

\section{The effect of dietary sodium modification on blood pressure in adults with systolic blood pressure less than $140 \mathrm{mmHg}$ : A systematic review}

Kelly, Jaimon; Khalesi, Saman; Dickinson, Kacie; Hines, Sonia; Coombes, Jeff S; Todd, Alwyn S

Published in:

JBI Database of Systematic Reviews and Implementation Reports

DOI:

10.11124/JBISRIR-2016-002410

Licence:

Other

Link to output in Bond University research repository.

Recommended citation(APA):

Kelly, J., Khalesi, S., Dickinson, K., Hines, S., Coombes, J. S., \& Todd, A. S. (2016). The effect of dietary sodium modification on blood pressure in adults with systolic blood pressure less than $140 \mathrm{mmHg}$ : A systematic review. JBI Database of Systematic Reviews and Implementation Reports, 14(6), 196-237. https://doi.org/10.11124/JBISRIR-2016-002410

\section{General rights}

Copyright and moral rights for the publications made accessible in the public portal are retained by the authors and/or other copyright owners and it is a condition of accessing publications that users recognise and abide by the legal requirements associated with these rights.

For more information, or if you believe that this document breaches copyright, please contact the Bond University research repository coordinator. 


\title{
The effect of dietary sodium modification on blood pressure in studies of participants with systolic blood pressure less than 140mmHg: A systematic review
}

\author{
Jaimon Kelly, MNutrDiet, BHIthSc ${ }^{1}$ \\ Saman Khalesi, MSc, PhD candidate ${ }^{2}$ \\ Kacie Dickinson, APD, PhD, BNutDiet (Hons) ${ }^{3}$ \\ Sonia Hines, RN, BN, Grad Dip Ed (Tertiary \& Adult), MAppSci (Research) ${ }^{4}$ \\ Jeff S. Coombes, AEP, PhD, BAppSc, BEd (Hons), MEd ${ }^{5}$ \\ Alwyn S. Todd, APD, PhD, PGDipDiet, BSc (Nutrition) ${ }^{6}$
}

1. School of Allied Health Sciences, Griffith University, Queensland, and Faculty of Health Science and Medicine, Bond University, Queensland

2. Menzies Health Institute Queensland and School of Medicine, Griffith University, Queensland

3. Nutrition and Dietetics, School of Health Sciences, Faculty of Medicine, Nursing and Health Sciences, Flinders University, South Australia

4. Queensland Centre for Evidence Based Nursing and Midwifery: a Collaborating Centre of the Joanna Briggs Institute; and Nursing Research Centre, Mater Health Services, Queensland

5. School of Human Movement and Nutritional Sciences, University of Queensland, Queensland

6. Mater Research Institute- The University of Queensland, Queensland, and Menzies Health Institute Queensland, Griffith University, Queensland

Corresponding author: Dr Alwyn Todd, Email: alwyn.todd@griffith.edu.au

\section{Executive summary}

Background: Modifying dietary sodium intake is a cornerstone of diet advice for lowering blood pressure under the assumption that it is protective against cardiovascular disease. Previous meta-analyses of normotensive participants have not excluded all studies that recruited participants with systolic blood pressure (SBP) $>140 \mathrm{mmHg}$, which greatly hinders generalization to the wider normotensive population.

Objectives: The objective of this review was to identify the effectiveness of reducing or increasing sodium intake on blood pressure in normotensive participants with systolic blood pressure $\leq 140 \mathrm{mmHg}$.

\section{Inclusion criteria}

Types of participants: This review considered studies on adult participants ( $\geq 18$ years) with SBP $\leq 140 \mathrm{mmHg}$. Studies in pregnant women or patients prescribed antihypertensive or vasoactive medications were excluded.

Types of interventions: Interventions that quantitatively evaluated dietary sodium intake for equal to or greater than 4 weeks duration were considered. Only studies that included two study arms comprising of different levels of sodium intake were included.

Types of outcomes: Studies that reported systolic blood pressure (SBP), diastolic blood pressure (DBP), pulse wave velocity (PWV), pulse wave analysis, or flow mediated dilatation were considered.

Types of studies: Experimental study designs including randomized controlled trials and non-randomized controlled trials were considered.

Search strategy: An initial search strategy was conducted on databases MEDLINE and CINAHL before an extensive search of all relevant published and grey literature databases, and clinical trial registries were searched.

Methodological quality: Potential papers were assessed for methodological validity using the standardised critical appraisal instrument from the Joanna Briggs Institute Meta-Analysis of Statistics Assessment and Review Instrument (JBI-MAStARI). 
Data collection and synthesis: Quantitative data was extracted from papers using the standardised data extraction tool from JBI-MAStARI and pooled in statistical meta-analysis. Effect sizes were expressed as weighted mean differences and $95 \%$ confidence intervals. Metaanalysis was conducted using a random-effect model, and heterogeneity assessed statistically using the standard Chi square test and the $R$ index. Sub-group analyses were undertaken on studies achieving $\geq 40 \mathrm{mmol}$ versus $<40 \mathrm{mmol}$ in urinary sodium excretion, studies $\leq 12$ weeks and studies with a mean $\mathrm{BMI} \geq 30$ versus less than 30 .

\section{Results:}

Five trials were included with a total of 1214 participants. The overall reduction in SBP was $0.71 \mathrm{mmHg}(95 \% \mathrm{Cl}:-2.62,1.20, \mathrm{p}=0.47)$; and DBP $-0.57 \mathrm{mmHg}(95 \% \mathrm{Cl}:-1.26,0.12, \mathrm{p}=0.10)$. There was no significant change in PWV following reduction of dietary sodium over a four to six week period. Sub-group analysis did not find a significant effect of urinary sodium excretion, study duration $\leq 12$ weeks or BMI on outcomes, however trend towards a greater reduction in blood pressure was observed in those with a higher BMI (MD $-2.41,95 \% \mathrm{Cl}-5.72$, $+0.91, p=0.16$ ).

Conclusions: Blood pressure in normotensive participants was not significantly affected by sodium modification, and was controlled to within $1 \%$ of baseline values overall and with extended study duration. Reducing dietary sodium in normotensive participants may still be of importance for cardiovascular risk management, however good quality interventional research is limited.

Implications for Practice: Healthy normotensive populations effectively respond to changes in sodium intake by regulating blood pressure. Sodium reduction may still be cardio-protective but given the lack of data from intervention studies on the safety and efficacy of very low levels of sodium intake $(<1500 \mathrm{mg} /$ day) in those with normal blood pressure, superfluous sodium restriction should be avoided.

Implications for Research: To better understand true normotensive blood pressure response, and the impact of sodium on cardiovascular risk, further intervention studies in subjects with SBP $\leq 130-140 \mathrm{mmHg}$ are required. Studies should be at least 1-year in duration and follow up participant's cardiovascular risk and outcomes long term.

Keywords: Normotensive, normotension, blood pressure, pulse wave analysis, salt, sodium 
Summary of findings:

\section{Low sodium compared to High sodium in Normotensive subjects}

Patient or population: Normotensive subjects

Setting: Community settings (i.e. free living populations) and controlled conditions (e.g. metabolic ward, hospital, study centre)

Intervention: Low sodium

Comparison: High sodium

\begin{tabular}{|c|c|c|c|c|c|}
\hline \multirow[t]{2}{*}{ Outcomes } & \multicolumn{2}{|c|}{ Anticipated absolute effects* $(95 \% \mathrm{Cl})$} & \multirow{2}{*}{$\begin{array}{l}\text { № of } \\
\text { participants } \\
\text { (studies) }\end{array}$} & \multirow{2}{*}{$\begin{array}{l}\text { Quality of the } \\
\text { evidence } \\
\text { (GRADE) }\end{array}$} & \multirow[t]{2}{*}{ Comments } \\
\hline & $\begin{array}{l}\text { Risk with High } \\
\text { sodium }\end{array}$ & Risk with Low sodium & & & \\
\hline $\begin{array}{l}\text { Change in } \\
\text { systolic blood } \\
\text { pressure (SBP) } \\
\text { assessed with: } \\
\mathrm{mmHg} \\
\text { follow up: range } \\
4 \text { weeks to } 36 \\
\text { months }\end{array}$ & $\begin{array}{l}\text { The mean change } \\
\text { in systolic blood } \\
\text { pressure ranged } \\
\text { from }-2.8 \text { to } 3.0\end{array}$ & $\begin{array}{l}\text { The mean change in systolic } \\
\text { blood pressure in the } \\
\text { intervention group was } 0.71 \\
\text { lower ( } 2.62 \text { lower to } 1.2 \\
\text { higher) }\end{array}$ & $\begin{array}{l}1399 \\
\text { (5 RCTs) }\end{array}$ & $\begin{array}{l}\bigoplus \bigoplus \bigoplus \bigoplus \\
\mathrm{HIGH}\end{array}$ & $\begin{array}{l}\text { Moderate heterogeneity was } \\
\text { observed. Strict inclusion criteria } \\
\text { reduced the risk of bias but limited the } \\
\text { number of studies available for } \\
\text { pooling. }\end{array}$ \\
\hline $\begin{array}{l}\text { Change in } \\
\text { diastolic blood } \\
\text { pressure } \\
\text { (DBP) } \\
\text { assessed with: } \\
\mathrm{mmHg} \\
\text { follow up: range } \\
4 \text { weeks to } 36 \\
\text { months }\end{array}$ & $\begin{array}{l}\text { The mean change } \\
\text { in diastolic blood } \\
\text { pressure ranged } \\
\text { from }-2.4 \text { to }+2.4\end{array}$ & $\begin{array}{l}\text { The mean change in } \\
\text { diastolic blood pressure in } \\
\text { the intervention group was } \\
0.57 \text { lower ( } 1.26 \text { lower to } \\
0.12 \text { higher) }\end{array}$ & $\begin{array}{l}1399 \\
\text { (5 RCTs) }\end{array}$ & $\begin{array}{l}\bigoplus \bigoplus \bigoplus \bigoplus \bigoplus \\
\text { HIGH }\end{array}$ & Low heterogeneity was observed. \\
\hline $\begin{array}{l}\text { Changes in } \\
\text { pulse wave } \\
\text { velocity (PWV) } \\
\text { assessed with: } \\
\mathrm{m} / \mathrm{s} \\
\text { follow up: range } \\
4 \text { weeks to } 6 \\
\text { weeks }\end{array}$ & $\begin{array}{l}\text { The mean changes } \\
\text { in pulse wave } \\
\text { velocity ranged } \\
\text { from }-1.4 \text { to }+0.13 \\
\mathrm{~m} / \mathrm{s}\end{array}$ & $\begin{array}{l}\text { The mean changes in pulse } \\
\text { wave velocity in the } \\
\text { intervention group was } 0.82 \\
\mathrm{~m} / \mathrm{s} \text { higher ( } 0.7 \text { lower to } 2.33 \\
\text { higher) }\end{array}$ & $\begin{array}{l}100 \\
\text { (2 RCTs) }\end{array}$ & $\begin{array}{l}\bigoplus \bigoplus \bigoplus \bigcirc \\
\text { MODERATE } 1 \underline{2} \underline{3}\end{array}$ & $\begin{array}{l}\text { Low heterogeneity was observed. Few } \\
\text { published trials and the small sample } \\
\text { size may have limited the ability of this } \\
\text { meta-analysis to detect a significant } \\
\text { change }\end{array}$ \\
\hline
\end{tabular}

${ }^{*}$ The risk in the intervention group (and its $95 \%$ confidence interval) is based on the assumed risk in the comparison group and the relative effect of the intervention (and its $95 \% \mathrm{Cl}$ ).

Cl: Confidence interval; RR: Risk ratio; OR: Odds ratio;

\section{GRADE Working Group grades of evidence}

High quality: We are very confident that the true effect lies close to that of the estimate of the effect

Moderate quality: We are moderately confident in the effect estimate: The true effect is likely to be close to the estimate of the effect, but there is a possibility that it is substantially different

Low quality: Our confidence in the effect estimate is limited: The true effect may be substantially different from the estimate of the effect

Very low quality: We have very little confidence in the effect estimate: The true effect is likely to be substantially different from the estimate of effect

\footnotetext{
1. Publication bias not detected with searching of clinical trial registries and grey literature

2. Small sample size

3. Pooling of data from non-obese and obese subjects
} 


\section{Introduction}

\section{Background}

Hypertension is a significant risk factor for cardiovascular disease (CVD) and has been identified as the leading single risk factor in the global burden of disease ${ }^{1,2}$ Hypertension guidelines frequently recommend salt reduction as an important simple strategy to reduce high blood pressure. ${ }^{2-4}$ This recommendation is often extended to normotensive individuals as well, particularly those at risk of becoming hypertensive. ${ }^{5}$ However, it has not been conclusively shown that dietary sodium reduction in normotensive adults is effective in lowering blood pressure.

The pressure-natriuresis relationship that was first described by Guyton ${ }^{6}$ proposes a link between dietary sodium intake and renal sodium handling. Specifically, the hypothesis states that in a normal individual, consumption of a dietary sodium load will elicit a transient rise in blood pressure that stimulates the kidney to excrete sodium. The kidney will excrete excess sodium leading to restoration of normal blood pressure. This hypothesis explains how blood pressure is maintained over the longer term even though most individuals report day-to-day variation in sodium intake.6, 7 Following this hypothesis, intervention studies in normotensive subjects may be expected to observe a small amount of variation in blood pressure with changes to dietary sodium intake, but this variation should be small enough to be considered clinically irrelevant. Intervention studies examining the effect of dietary sodium have reported a range of different responses; from significant changes ${ }^{8,9}$ to moderate effects on blood pressure, to no effect at all.10-12 Normotensive studies that report blood pressure changes over the longer term have previously documented changes in systolic blood pressure (SBP) ranging from $1 \mathrm{mmHg}^{12}$ to increases of $8.2 \mathrm{mmHg}{ }^{8}$ This variation may be largely explained by the inclusion of participants with SBP $>140 \mathrm{mmHg}$ in earlier normotensive studies, or the exclusion of subjects with SBP $<120 \mathrm{mmHg}$.

We searched Cochrane and $\mathrm{JBI}$ libraries, Prospero and Medline and identified three previous systematic reviews of blood pressure response to dietary sodium restriction. ${ }^{13-15}$ Unfortunately we also identified a major limitation common to all three reviews ${ }^{14}$ and those with an element of selection bias, from pooled results. Whilst some may argue that normotensive response to sodium is irrelevant, it is actually critically important for interpretation of evidence in clinical practice that a baseline response to dietary sodium is established. A stronger and more robust analysis of response would also assist in the development of future clinical trials and public health recommendations, such as WHO guidance and dietary guidelines ${ }^{2,16}$.

If the blood pressure reduction in truly normotensive subjects is indeed clinically irrelevant, as Guytons hypothesis suggests it should be, future recommendations for sodium reduction in normotensive populations with no other blood pressure risk factors would need to establish other cardiovascular benefits, such as effects on other markers of arterial function or a direct reduction in cardiovascular risk. Whilst literature does not currently provide sufficient quality evidence to directly link sodium intake with mortality in normotensive subjects ${ }^{5}$, it will be important for future reviews to consider this if large scale intervention studies are ever conducted. A number of randomised controlled trials have however investigated the effects of dietary sodium intake on arterial function, and found that these effects may be at least partly independent of blood pressure. ${ }^{17-22}$ As these effects may be key in extending our understanding of sodium intake and disease risk, they form part of the bigger picture for dietary sodium intake and chronic disease risk. It is therefore important to consider data on arterial function such as pulse wave analysis, pulse wave velocity and flow mediated dilation in current and future meta-analyses of sodium restriction.

A revised systematic review and meta-analysis of normotensive response to sodium modification is required. ${ }^{23}$ This systematic review will consider the evidence for longer term dietary sodium restriction in participants with SBP $<140 \mathrm{mmHg}$ on arterial function.

\section{Objectives}


The objectives are to identify the effect of reducing or increasing sodium intake on blood pressure in normotensive adults with SBP $\leq 140 \mathrm{mmHg}$, and the effect of sodium reduction or supplementation on arterial function in participants with baseline SBP $\leq 140 \mathrm{mmHg}$.

\section{Inclusion criteria}

\section{Types of participants}

This review considered studies on adult participants with SBP $\leq 140 \mathrm{mmHg}$ conducted in community settings (i.e. free living populations) and controlled conditions (e.g. metabolic ward, hospital, study centre). Studies in pregnant women or participants prescribed antihypertensive or vasoactive medications were excluded.

\section{Types of interventions}

Interventions that evaluated dietary sodium intake for $\geq 4$ week's duration were considered. Only studies that included two study arms comprising of different levels of sodium intake, and that modified sodium intake via dietary modification, salt reduction and/or salt supplementation were included.

\section{Types of outcomes}

Studies that reported SBP, diastolic blood pressure (DBP), pulse wave velocity, pulse wave analysis, or flow mediated dilatation (FMD) by Doppler ultrasound were considered.

\section{Types of studies}

Experimental study designs including randomized controlled trials and non-randomized controlled trials were considered. Studies with an element of selection bias (e.g. normotensive studies that excluded subjects with systolic blood pressure $<120 \mathrm{mmHg}$ ) were excluded.

\section{Search strategy}

The search strategy (Appendix I) endeavoured to find both published and unpublished studies. A threestep search strategy was utilised in this review. An initial limited search of MEDLINE and CINAHL was undertaken followed by analysis of the text words contained in the title and abstract, and of the index terms used to describe article. A second search using all identified keywords and index terms was then undertaken across all included databases. Thirdly, the reference lists of all identified reports and articles were searched for additional studies. Studies published in any language were considered for inclusion in this review, with non-English publications translated to English. Titles and/or abstracts published in non-English language were translated before decision to include or exclude. Studies published between 1980 and the present day were considered for inclusion in this review. Prior to 1980, the definition of normotension exceeded $160 \mathrm{mmHg}$ systole. In addition, such studies were not well controlled or reported as per the CONSORT statement. ${ }^{24}$

The databases searched included; MEDLINE, CINAHL, PROQUEST, Scopus, EMBASE, Cochrane Library, and Wiley InterScience. Additionally clinical trial registrars Australia and New Zealand Clinical Trials Registry, ClinicalTrials.gov, ISRCTN, WHOICTRP were searched using the search terms listed below. These registries were rechecked prior to manuscript submission to ensure no other recently published studies matched the inclusion criteria of this review. The search for unpublished studies included: Proquest Dissertations and Theses Database, Dissertations and Theses International, Mednar, OpenSIGLE, EAGLE. Initial keywords used were: sodium, salt, blood pressure, normotens*, systolic, diastolic, pulse wave, controlled, endothelial function, diabet*

\section{Method of the review}

\section{Critical appraisal}

Potential papers selected for retrieval were assessed for methodological validity prior to inclusion using the standardised critical appraisal instrument from the Joanna Briggs Institute Meta-Analysis of Statistics Assessment and Review Instrument (JBI-MAStARI; Appendix II). The papers retrieved were assessed by two reviewers (SK, JK) prior to inclusion in the review using standardised critical appraisal instruments from the Joanna Briggs Institute Meta-Analysis of Statistics Assessment and Review Instrument (JBI-MAStARI) (Appendix II). The JBI_MAStARI tool captured study design limitations and 
the critical appraisal process also identified elements of selection bias (e.g. studies excluding true normotensive participants $<120 \mathrm{mmHg}$ ) and variation within interventions such as the dose, method and duration of dietary sodium modification that were evaluated. Where a a study scored poorly on the JBIMASTARI tool or a high level of selection bias (eg. exclusion of participants with SBP $<120 \mathrm{mmHg}$ ) or significant confounding was identified, studies were excluded from the review. Any disagreements that arose between the reviewers were resolved through discussion, or through a third reviewer (KD or AT). Where a reviewer had been involved in research work that had resulted in the publication of an included study, the respective study was assigned to an alternative reviewer for quality analysis.

\section{Data collection}

Quantitative data were extracted from papers included in the review using the standardised data extraction tool from JBI-MAStARI (see Appendix III). The data were extracted independently by two reviewers (JK, SK), and included specific details about the interventions, populations, study methods and outcomes of significance to the review question and specific objectives. Any difference in data extraction was resolved through discussion, or by a third reviewer (AT). A process reviewer checked adherence to study protocol $(\mathrm{SH})$. For studies with missing data, an attempt was made to contact corresponding authors in order to make a decision about the studies eligibility and/or to include in our analysis.

\section{Data synthesis}

For each trial retrieved, outcome variables for overall treatment effect were calculated. For crossover trials, the calculated treatment effect was the difference between end of reduced sodium period and the end of control period from baseline. For parallel trials, the treatment effect was the difference between the intervention (i.e. reduced dietary sodium) and control groups change from baseline to the end of follow-up for each of the measured outcomes. A correlation coefficient $(r)$ of 0.5 was used to impute the missing SD of change. ${ }^{19}$ The SD of net change for cross-over trials was also imputed using $r=0.5$. Quantitative data was, where possible, pooled in statistical meta-analysis using RevMan (version 5.3.3). All results were subject to double data entry. Due to the variation observed in the characteristic of trials included, the DerSimonian and Laird random-effect model was used in conducting the meta-analysis. Heterogeneity assessed statistically using the standard Chi square and the $l^{2}$ index. An $l^{2}$ value of $25 \%$ was considered to represent low heterogeneity, and $75 \%$ high heterogeneity. ${ }^{25}$ Values were considered statistically different from zero using a Z-test analysis where $p<0.05$ was observed. Where statistical pooling was not possible the findings were presented in narrative form including tables and figures to aid in data presentation where appropriate. A one-by-one sensitivity analysis was performed by assessing the effect of individual studies on the overall results of meta-analysis. To assess the robustness of chosen correlation coefficient, sensitivity analysis of alternative coefficients $(r=0.2$ and 0.8 ) was also conducted. Sub-group analyses were planned to examine studies recruiting participants with SBP $\leq 130 \mathrm{mmHg}$, studies achieving a $40 \mathrm{mmol}$ or greater reduction in urinary sodium excretion, studies conducted in participants of different ethnicities, and studies conducted in those with and without a diagnosis of diabetes. We only identified one study each in participants with SBP $\leqslant 130 \mathrm{mmHg}$, participants of African American ethnicity, and in participants with diabetes, therefore sub-group analysis was not conducted.

\section{Results}

\section{Number of studies found and retrieved}

The search strategy identified 1724 studies, from which 1491 were excluded on the basis of title and abstract review. Upon detailed review, 221 articles were excluded primarily for reasons outlined in the PRISMA flow chart (see Figure 1). The most common reasons for exclusion were inclusion of participants with baseline systolic blood pressure above $>140 \mathrm{mmHg}$, use of antihypertensive medications, or study duration less than four weeks (see appendix IV for excluded studies). A total of 12 studies were initially retrieved but following eligibility assessment a further seven were excluded for being outside the inclusion criteria for this review. Two of these studies ${ }^{26,27}$ were excluded following contact with authors that confirmed both studies had five percent of participants with SBP greater than $140 \mathrm{mmHg}$ at baseline. Two studies ${ }^{28,} 29$ did not have values for SBP inclusion at baseline and were excluded when the authors were unable to provide appropriate statistical data, and one study used a $25 \%$ potassium chloride salt substitute and reported a four-fold greater increase in potassium excretion in the intervention group compared with the control group. ${ }^{30}$ Two further studies ${ }^{31,32}$ were excluded, as 
they only recruited pre-hypertensive participants and excluded participants with SBP $<120 \mathrm{mmHg}$. These studies were not considered of appropriate design to inform the main objective of this review to establish the effect of modifying dietary sodium intake in normotensive participants, due to the significant population of normotensive subjects that were excluded. The exclusion of subjects with $\mathrm{SBP}<120 \mathrm{mmHg}$ was considered to introduce a significant element of selection bias that was likely to impact the outcome of these studies. Further identification of potential studies was carried out by analysing all included studies' reference lists, and one additional study was retrieved. Following quality analysis one further study ${ }^{33}$ was excluded (Table 1) to give a total of five studies. One non-English study was identified as meeting the inclusion criteria, ${ }^{33}$ this study was available in English format and was excluded on quality assessment. One study reported the SD of change from baseline ${ }^{7}$ however mean (SD) of outcome measures were not reported and a correlation coefficient could not be calculated. ${ }^{19}$

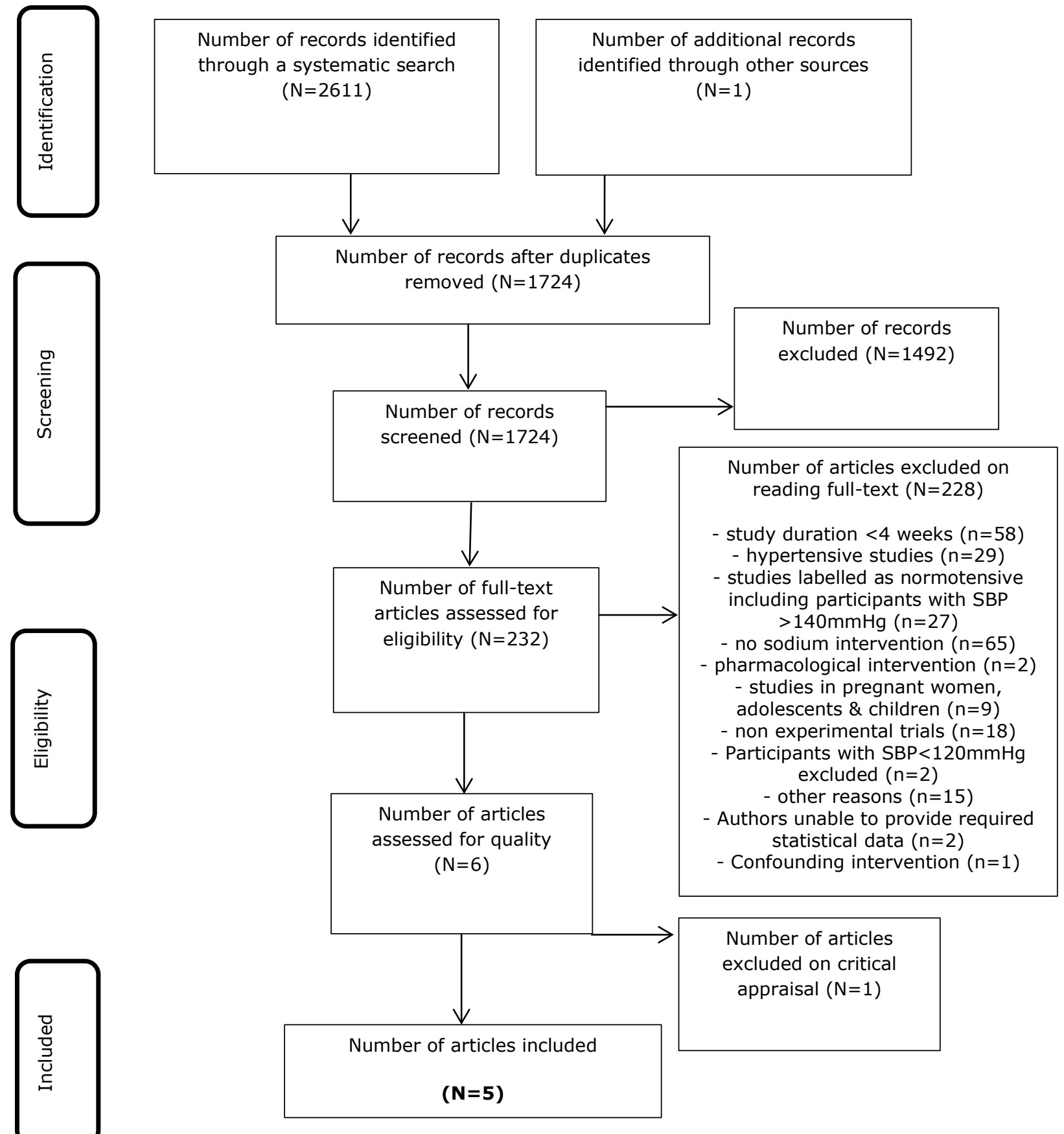

Figure 1: Flow-chart for the search and study selection process

\section{Description of studies}


Of the five articles retrieved and included in the meta-analysis, four were crossover designs, ${ }^{10}, 11,20,34$ and one was a parallel study design. ${ }^{12}$ Three studies were in Caucasians, ${ }^{10,11,20}$ one was in a African American population, ${ }^{34}$ and one was mixed race. ${ }^{12}$ All studies utilised different BMI cut-offs, two included obese participants $^{12,20}$ and two were in non-obese participants. ${ }^{10,11}$ One study did not include BMI as an inclusion or exclusion criteria. ${ }^{34}$ Two studies $^{10,11}$ implemented four week duration interventions, one implemented a six week intervention, ${ }^{20}$ another an eight week intervention. ${ }^{34}$ The longest study ran for 48 months, with data collected on all participants for a minimum of 36 months. ${ }^{12}$ All five articles reported SBP and DBP, two studies reported PWV, ${ }^{11,20}$ and one study reported FMD. ${ }^{20}$ Physical activity was not reported in the five included studies.

\section{Methodological quality}

Methodological quality was moderate-to-high across all included studies (see Table 1). Randomisation procedures were adequate in the majority of the included studies and all treatment groups were comparable at entry and treated identical throughout the treatment period. Blinding of study personnel was only possible in one study, although blinding of the participant was only done in two of the included studies, achieving this type of blinding is generally difficult in dietary studies, ${ }^{35}$ and is reduced by ensuring all outcome assessors are blind to the randomisation allocation, which was done adequately in four of the five studies. 
Table 1: Quality assessment of the included studies.

\begin{tabular}{|l|c|c|c|c|c|c|c|c|c|c|}
\hline Citation & Q1 & Q2 & Q3 & Q4 & Q5 & Q6 & Q7 & Q8 & Q9 & Q10 \\
\hline $\begin{array}{l}\text { Dickinson, Keogh JB, Clifton PM, } \\
2014\end{array}$ & $\mathrm{~N}$ & $\mathrm{~N}$ & $\mathrm{Y}$ & $\mathrm{Y}$ & $\mathrm{Y}$ & $\mathrm{Y}$ & $\mathrm{Y}$ & $\mathrm{Y}$ & $\mathrm{Y}$ & $\mathrm{Y}$ \\
\hline $\begin{array}{l}\text { Flack J, Grimm Jr R, Staffileno B, } \\
\text { Elmer P, Yunis C, Hedquist L, et. } \\
\text { al, 2001 }\end{array}$ & $\mathrm{Y}$ & $\mathrm{Y}$ & $\mathrm{U}$ & $\mathrm{U}$ & $\mathrm{Y}$ & $\mathrm{Y}$ & $\mathrm{Y}$ & $\mathrm{Y}$ & $\mathrm{Y}$ & $\mathrm{U}$ \\
\hline $\begin{array}{l}\text { Ruppert M, Overlack A, } \\
\text { Kolloch R, Kraft K, Göbel B, } \\
\text { Stumpe KO, 1993 }\end{array}$ & $\mathrm{Y}$ & $\mathrm{Y}$ & $\mathrm{U}$ & $\mathrm{Y}$ & $\mathrm{N}$ & $\mathrm{Y}$ & $\mathrm{Y}$ & $\mathrm{Y}$ & $\mathrm{Y}$ & $\mathrm{U}$ \\
\hline $\begin{array}{l}\text { Todd AS, MacGinley RJ, } \\
\text { Schollum JB, Williams SM, } \\
\text { Sutherland WH, Mann JI, } \\
\text { Walker RJ, 2012 }\end{array}$ & $\mathrm{Y}$ & $\mathrm{N}$ & $\mathrm{N}$ & $\mathrm{Y}$ & $\mathrm{Y}$ & $\mathrm{Y}$ & $\mathrm{Y}$ & $\mathrm{Y}$ & $\mathrm{Y}$ & $\mathrm{Y}$ \\
\hline $\begin{array}{l}\text { Trials of Hypertension } \\
\begin{array}{l}\text { Prevention Collaborative } \\
\text { Research Group, 1997 }\end{array}\end{array}$ & $\mathrm{Y}$ & $\mathrm{N}$ & $\mathrm{U}$ & $\mathrm{Y}$ & $\mathrm{U}$ & $\mathrm{Y}$ & $\mathrm{Y}$ & $\mathrm{Y}$ & $\mathrm{Y}$ & $\mathrm{Y}$ \\
\hline $\begin{array}{l}\text { \% Total } \\
\text { Tal }\end{array}$ & $80 \%$ & $40 \%$ & $20 \%$ & $80 \%$ & $80 \%$ & $100 \%$ & $100 \%$ & $100 \%$ & $100 \%$ & $60 \%$ \\
\hline
\end{tabular}

\section{Results of the quantitative analysis}

\section{Effects of sodium reduction interventions:}

A total of five trials with eight comparisons encompassed 1214 participants. The characteristics of studies included in this meta-analysis are presented in Appendix $V$. The mean blood pressure in the control/high sodium intake groups was $119.4 / 76.9 \mathrm{mmHg}$. Estimated sodium excretion on usual sodium intake based on 24 -hour collections and dietary intervention targets, was $175 \mathrm{mmol}$ (10 g/day salt), ranging from 134 to $190 \mathrm{mmol}$ (8- 
$11 \mathrm{~g} /$ day salt). The estimated change in dietary sodium from the usual to the reduced salt intake was $-75 \mathrm{mmol} /$ day (range -37 to $-136 \mathrm{mmol}$ ), equivalent to a reduction in sodium intake $4 \mathrm{~g} /$ day (range $2-8 \mathrm{~g} /$ day).

\section{High sodium versus low sodium for blood pressure in all participants}

Five trials $(n=1214)$ were retrieved with data available for SBP; with a mean difference $(M D)$ of $-0.71 \mathrm{mmHg}(95 \% \mathrm{Cl}:-2.62,1.20)$. There was no significant change in SBP following reduction of dietary sodium over the period of four weeks to 36 months $(\mathrm{p}=0.48$ see Figure 2). The data displayed a moderate degree of heterogeneity $\left(\mathrm{Chi}^{2}=8.77, \mathrm{p}=0.07 ; \mathrm{I}^{2}=54 \%\right)$ likely due to study design factors, such as the recruitment of obese subjects in two studies. ${ }^{12,20}$

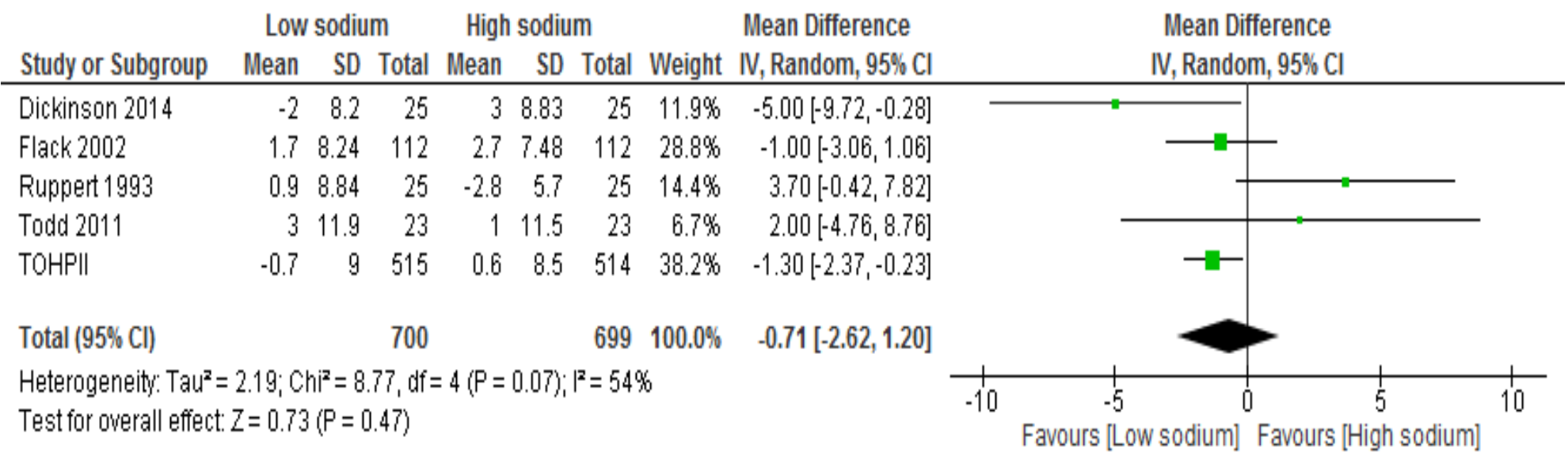

Figure 2: Forest plot of the effect of salt modification on systolic blood pressure. The effectiveness of salt modification is presented using random effect. The mean and SD of changes from baseline are reported for trials. Effects of trial are presented as weight (\%) and mean difference $(95 \% \mathrm{Cl})$. The size of the box and its location on horizontal line represents the weight of each study; the variance reported by each study is represented by the horizontal line.

A total of five trials $(n=1214)$ for DBP (Figure 3) had a MD of $-0.57 \mathrm{mmHg}(95 \% \mathrm{Cl}:-1.26,0.12)$. There was no significant change in DBP following reduction of dietary sodium over the period of four weeks to 36 months $(p=0.10)$. The data had low heterogeneity $\left(\mathrm{Chi}^{2}=3.21, p=0.52 ; \mathrm{I}^{2}=0 \%\right)$. Sensitivity analysis excluded individual studies and assessed the effect on overall results of meta-analysis. No significant effect on meta-analysis was observed by excluding any study on mean difference of DBP. 


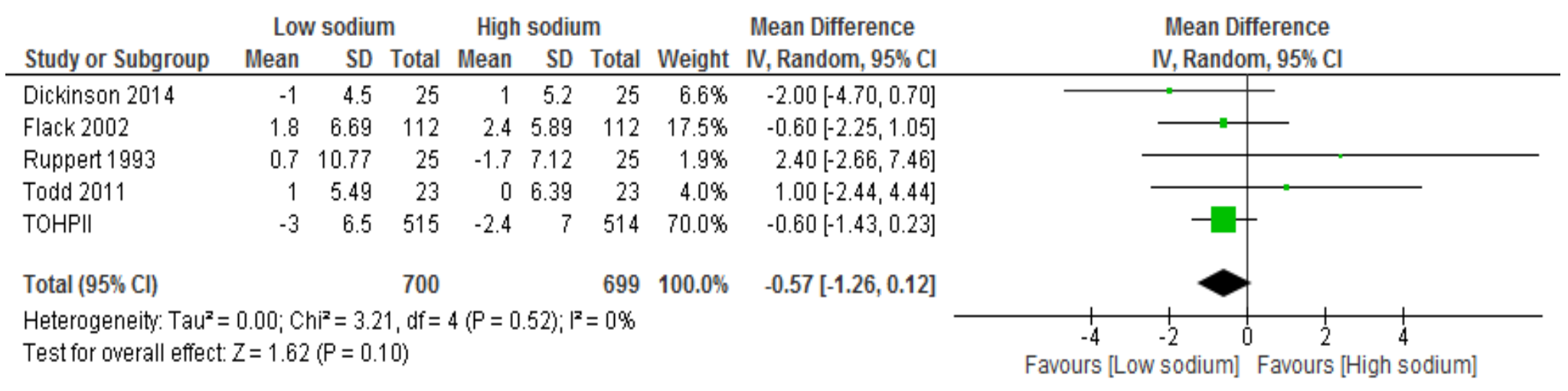

Figure 3: Forest plot of the effect of salt modification on diastolic blood pressure. The effectiveness of salt modification is presented using random effect. The mean and SD of changes from baseline are reported for trials. Effect of trial are presented as weight (\%) and mean difference $(95 \% \mathrm{Cl})$. The size of the box and its location on horizontal line represents the weight of each study; the variance reported by each study is presented by the horizontal line

Sub-analysis of four trials with urinary sodium excretion $>40 \mathrm{mmol} /$ day gave four comparisons encompassing 1102 participants with a MD of -0.40 (95\% $\mathrm{Cl}:-3.61,2.81 ; p=0.81$ ) (Table2). Sub-group analyses were originally planned to examine studies recruiting participants with $\mathrm{SBP} \leq 130 \mathrm{mmHg}$, participants of different ethnicities, participants with and without diabetes. Only one study was located that presented data for participants with SBP $<130 \mathrm{mmHg}^{11}$ and only one study was included, that presented data for participants of African American ethnicity, ${ }^{34}$ therefore sub-analyses were not conducted. No studies were available in participants with diabetes.

Subgroup analysis of the duration of intervention showed a non-significant reduction of SBP and DBP when intervention duration is $\leq 12$ weeks. The subgroup of cross-over design of the study did not show any statistically significant results. We also planned to present between group analyses for study design (parallel versus cross-over), and sodium excretion $(>40 \mathrm{mmol}$ versus $<40 \mathrm{mmol} / 24$ hours), however only one study was available for participants with a sodium reduction of $<40 \mathrm{mmol} / 24$ hours and only one study was of parallel design.

Subgroup analysis also explored the sources of heterogeneity observed in meta-analysis results of SBP. A high heterogeneity was observed with subgroup of studies with intervention duration $\leq 12$ weeks $(74 \%)$. This may suggest an influence of study duration on the heterogeneity of results, however we are unable to confirm this as as only one study satisfies the $\geq 12$ week study duration criteria. Baseline BMI of participants did not have a statistically significant effect on the meta-analyses of BP. However, a trend was observed with more pronounced reduction of both SBP and DBP in the subgroup of participants with mean baseline BMI $>=30 \mathrm{~kg} / \mathrm{m}^{2}$, compared to those with mean BMI $<30 \mathrm{~kg} / \mathrm{m}^{2}$ (Table 2). The test for subgroup difference was not significant for the effect of baseline BMI on BP. 
Table 2: Subgroup analysis of normotensive response to sodium modification by duration, achieved sodium reduction and design

\begin{tabular}{|c|c|c|c|c|c|}
\hline Subgroups & $\begin{array}{l}\text { Trials, } \\
\text { n }\end{array}$ & $\begin{array}{c}\text { Mean difference }(95 \% \mathrm{Cl}) \text { of SBP, } \\
\mathrm{mm} \mathrm{Hg}\end{array}$ & $\begin{array}{l}\text { Test for } \\
\text { subgroup } \\
\text { difference }\end{array}$ & $\begin{array}{c}\text { Mean difference }(95 \% \mathrm{Cl}) \text { of } \\
\text { DBP, } \mathrm{mm} \mathrm{Hg}\end{array}$ & $\begin{array}{l}\text { Test for subgroup } \\
\text { difference }\end{array}$ \\
\hline $\begin{array}{l}\text { Intervention duration } \\
\leq 12 \text { weeks }\end{array}$ & $n=4$ & $-0.24\left(-3.62,3.13 ; \rho=0.89 ; I^{2}=64 \%\right)$ & & $-0.48\left(-1.83,0.86 ; \rho=0.95 ; l^{2}=6 \%\right)$ & \\
\hline $\begin{array}{l}\text { Baseline BMI } \geq 30 \\
\mathrm{~kg} / \mathrm{m}^{2}\end{array}$ & $n=2$ & $-2.41\left(-5.72,0.91 ; \rho=0.16 ; P^{2}=55 \%\right)$ & $P^{2}=51 \%, \rho=0.15$ & $-0.72\left(-1.51,0.07 ; \rho=0.07 ; l^{2}=0 \%\right)$ & $P^{2}=0 \%, \rho=0.45$ \\
\hline $\begin{array}{l}\text { Baseline } \mathrm{BMI}<30 \\
\mathrm{~kg} / \mathrm{m}^{2}\end{array}$ & $n=3$ & $-0.71\left(-2.62,1.20 ; \rho=0.55 ; l^{2}=54 \%\right)$ & & $-0.09\left(-1.51,1.34 ; \rho=0.91 ; l^{2}=0 \%\right)$ & \\
\hline $\begin{array}{l}\text { Reduction in sodium } \\
\text { excretion } \geq 40 \\
\text { mmol/24 hours }\end{array}$ & $n=4$ & $-0.40\left(-3.61,2.81 ; \rho=0.81 ; I^{2}=66 \%\right)$ & & $-0.55\left[-1.14,0.03 ; \rho=0.71 ; I^{2}=6 \%\right)$ & \\
\hline Design (Cross-over) & $n=4$ & $-0.24\left(-3.62,3.13 ; \rho=0.89 ; I^{2}=64 \%\right)$ & & $-0.48\left(-1.83,0.86 ; \rho=0.48 ; l^{2}=6 \%\right)$ & \\
\hline $\begin{array}{l}\text { All trials (meta- } \\
\text { analysis result) }\end{array}$ & $n=5$ & $-0.71\left(-2.62,1.20 ; \rho=0.47 ; I^{2}=54 \%\right)$ & & $-0.57\left(-1.26,0.12 ; \rho=0.10 ; I^{2}=0 \%\right)$ & \\
\hline
\end{tabular}

1- Abbreviations used in this table: DBP: Diastolic blood pressure; SBP: Systolic blood pressure, BMI: Body-mass index

2- Changes in systolic and diastolic blood pressure are presented as mean difference and $95 \%$ confidence interval. Heterogeneity $\left(l^{2}\right)$ is presented

by $\%$. A p-value $<0.05$ is considered significant.

\section{High sodium versus low sodium for PWV in all participants}

Of two trials, with two comparisons for PWV (Figure 4), 48 participants had a MD of $82 \mathrm{~m} / \mathrm{s}(95 \% \mathrm{Cl}-1.26,0.12)$. There was no significant change in PWV following reduction of dietary sodium over the period of four to six weeks $(p=0.29)$. We were unable to perform a meta-analysis on FMD, because not enough studies met inclusion criteria. 


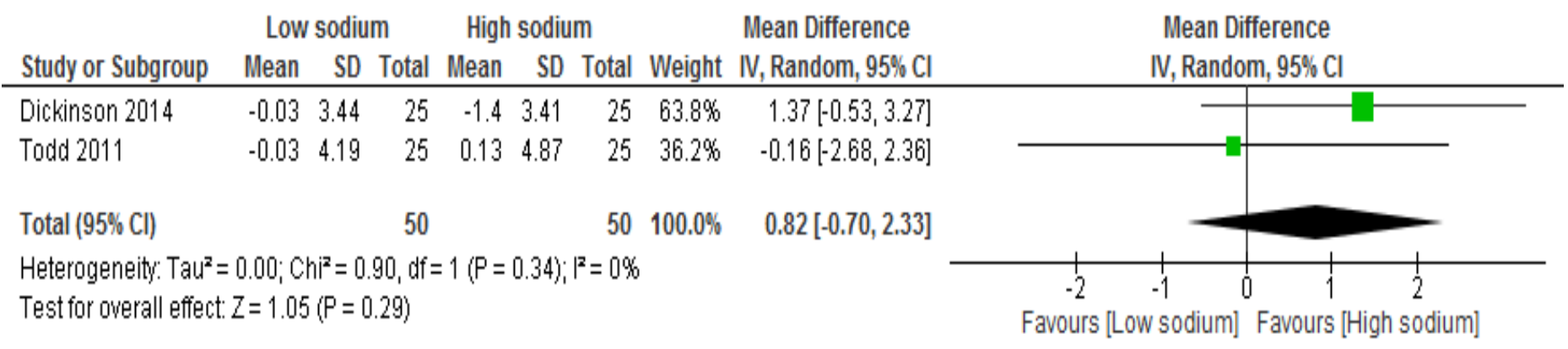

Figure 4: Forest plot of the effect of sodium modification on pulse wave velocity. The effectiveness of sodium modification is presented using random effect. The mean and SD of changes from baseline are reported for trials. The effect of each trial is presented as weight $(\%)$ and mean difference $(95 \% \mathrm{Cl})$. The size of the box and its location on horizontal line represents the weight of each study. The variance reported by each study is represented by the horizontal line

\section{Sensitivity analysis}

The sensitivity analysis of individual studies showed a significant effect of one study on SBP ${ }^{10}$. This may be due to 19 of the 25 participants in this study being classified as salt-resistant prior to study commencement, reducing the likelihood of a blood pressure response to dietary sodium.

Excluding this study showed a more pronounced effect of dietary modification on overall meta-analysis results $(-1.34,95 \% \mathrm{Cl}:-2.46,-0.22, \mathrm{p}=0.02)$

However, no significant effect of individual studies was observed on DBP. Sensitivity analysis of alternative correlation coefficients $(r=0.2$ and 0.8$)$

also did not report any significant changes using different levels of correlation coefficient. These results suggest the robustness of the analysis using chosen correlation coefficient $(r=0.05)$ (Appendix VI). 


\section{Discussion}

As far as we are aware, this is the first meta-analysis to report the effects of reducing dietary sodium intake on blood pressure as-well as FMD and PWV as markers of arterial function in normotensive participants with SBP equal to or less than $140 \mathrm{mmHg}$; consistent with the current definition of normotension. ${ }^{36,37}$ The finding of this analysis is a reduction following long term sodium modification of just $0.6 \%$ of the participants' baseline SBP. This small change in blood pressure is not clinically significant, and indicates that modifying sodium intake in truly normotensive individuals is unlikely to produce a blood pressure benefit. Reduction in sodium intake in those who are high consumers, or those who are pre-hypertensive, or of African American descent may however curb age related rises in blood pressure and help to stem cardiovascular risk independent of blood pressure response.

The lack of blood pressure response to sodium modification in this combined sample of normotensive subjects is consistent with Guyton's hypothesis. This hypothesis provides an explanation for the truly normotensive kidney regulating blood pressure in a setting of dietary sodium loading or modification. Theoretically, acute phases of sodium loading or reduction should cause transient rises or falls in blood pressure, which are corrected by the normal functioning kidney after an initial period between one to two weeks. ${ }^{7}$ Blood pressure appears to have been effectively regulated by the kidney in the majority of subjects in this review and a marked increase in blood pressure was not sustained. Although the pooled results show little effect of sodium, it is worth noting that the five included studies varied in their findings, reporting a range of changes to SBP from $-5 \mathrm{mmHg}^{20}$ to $+3.7 \mathrm{mmHg} .^{10}$ This variation can likely be attributed to participant characteristics. Close examination of the methods of the studies included in this analysis indicate that differences in SBP response may be due to factors such as the presence of obesity, ${ }^{12,20}$ or inclusion of participants of African-American ethnicity. ${ }^{34}$

To test the robustness of our primary finding, we performed sub-analyses by intervention duration less than 12 weeks and studies achieving greater (verse less) than $40 \mathrm{mmol} /$ day sodium reduction. Both these subgroups had similar non-significant effects on SBP, robust to our primary finding, and thus consistent with Guyton's hypothesis.

Differences between the results of this meta-analysis and previous meta-analyses can be explained by the inclusion of studies. Previous meta-analyses included all studies on participants 'labelled' as normotensive, including those conducted over 20 years ago when the definition of high blood pressure was undergoing review. Many trials labelled as normotensive trials were conducted prior to $1993,26,38-$ 42 and the range of blood pressure readings observed in these trials is greater than the range of blood pressure readings observed in more recent studies of normotensive participants. ${ }^{10,20}$ Excluding early studies that include participants with SBP $>140 \mathrm{mmHg}$ is necessary in order to detect the true effect of sodium reduction in participants with normal or high normal blood pressure..$^{10}$ However, exclusion of these studies greatly limits the field of available literature that has previously been described in numerous reviews. We initially planned to include sub-analysis of studies in normotensive participants with absence of pre-hypertension (i.e. SBP $<130 \mathrm{mmHg}$ ), in black populations, and in diabetics; but too few studies were retrieved to enable this.

The inclusion of pre-hypertensive participants in some studies included in this analysis may also account for some of the heterogeneity, as pre-hypertensive participants have previously been shown to have a greater response to sodium than their normotensive counterparts. It is worth noting that the DASH-Sodium study ${ }^{31}$ was not included in this meta-analysis as it excluded the main population of interest- those with truly normotensive blood pressure (systolic blood pressure $<120 \mathrm{mmHg}$ ) and ran the intervention concurrently with other dietary changes that significantly altered potassium excretion. This study examined pre-hypertensive participants (SBP 120-140 mm Hg) and hypertensive participants. A reduction in sodium intake of $77 \mathrm{mmol}$ was observed in both the US diet arm and the DASH diet arm and the mean blood pressure on the US diet with high sodium intake was $128 / 81 \mathrm{mmHg}$ and this reduced by $-5.6 /-2.8 \mathrm{mmHg}$ following the low sodium intervention, in the pre-hypertensive subgroup.

\section{Urine sub-analysis}

A modest sodium reduction of $30 \mathrm{mmol} / 24$ hour has been proven in controlled and free-living situations to elicit a blood pressure response at a significant level. ${ }^{12,32,42,43}$ Previous trials have only included 
studies that had a 24-hour sodium urine excretion of $>40 \mathrm{mmol} /$ day. For consistency with other literature we performed a sub-analysis of trials that achieved a urinary sodium reduction of $40 \mathrm{mmol} /$ day was performed and resulted in a non-significant reduction in SBP of $-0.40(95 \% \mathrm{Cl}:-3.61,2.81 ; \mathrm{p}=0.81)$ (see Table 2). It appears that regardless of the dose of sodium reduction, the normotensive kidney is effective in regulating blood pressure, robust to the primary finding.

Twenty-four hour urine collections to measure sodium excretion are the most accurate marker of dietary sodium intake in both epidemiological and experimental studies of dietary sodium restriction. However, compliance with complete collections is difficult to achieve in participants. ${ }^{14}$ Two studies $^{11,34}$ did not measure 24 hour urinary sodium excretion and were not included in this sub-analysis as a result. In Todd et al., ${ }^{11}$ ongoing dietetic review in all interventions in addition to regular early morning spot urine tests were used in place of 24 hour urinary sodium excretion to ensure dietary compliance to the interventions. The other study by Flack et al. ${ }^{34}$ utilised a pooled 24 hour urinary (three individual eight hour collections) in addition to sodium pill counts in both interventions. These methods, although not the gold standard, have been shown to elicit significant differences in sodium excretion, ${ }^{19}$ and have a role in measuring compliance, while ensuring the relevance in a clinical setting and reducing burden to participants in longer term studies. Both trials detail interventions that would have placed considerable burden on participants, through the complex nature of their design and lengthy durations, of 18 and 26 weeks respectively.

\section{PWV and FMD Sub-analyses}

PWV reflects artery elasticity - the higher the velocity of pulse wave transmission, the less elastic the wall. ${ }^{44}$ Studies to date in normotensive participants have not yielded significant results in participants with SBP $<140 \mathrm{mmHg}{ }^{11}{ }^{11} 20,21$ Improvements previously reported have been conducted in populations with blood pressure ranges up to $160 \mathrm{mmHg}{ }^{45} \mathrm{FMD}$ has been shown to be impaired following sodium loading in two previous normotensive studies, the included study by Dickinson et al. ${ }^{20,21}$ These studies both document non- significant correlations between FMD and blood pressure ${ }^{20,21}$ and only moderate correlations to PWV in hypertensive participants $(r=0.52, \mathrm{P}<0.05) ; ;^{19}$ suggestive of blood pressure independent pathways to endothelial and arterial function.

\section{Relevance of the findings}

Despite the World Health Organisation and other government bodies reporting that sodium reduction can reduce blood pressure in normotensive individuals, $, 2,16$ this is not supported by the current available evidence. Previous analyses of data used to inform public health policy around sodium intake have not acknowledged the limitations of available randomised controlled trials, and have incorrectly included studies with hypertensive participants in normotensive analyses. This has resulted in a greater blood pressure lowering effect than that which actually exists in truly normotensive individuals.

The results of this meta-analysis clearly demonstrates that modifying dietary sodium in healthy normotensive populations is not clinically effective to reduce blood pressure at an individual level over a period of four months to one year. Blood pressure remained within $1 \%$ of the subjects baseline readings, and only two studies were included in this subgroup which makes it difficult to draw conclusion on the influence of higher duration of modification. Reducing blood pressure is only of significance if it results in a reduction in CVD, ${ }^{46,47}$ and it has been previously suggested that this does not occur until a sustained change of $2-3 \mathrm{mmHg}$ over the long term is achieved. ${ }^{47}$

Despite the lack of effect on blood pressure it is important to note that reducing sodium may still be important in normotensive participants at a population level, as it may help to reduce the age-related rise in blood pressure and cardiovascular risk. ${ }^{46,}{ }^{48-51}$ Although there is good evidence to suggest reduction of sodium intake from high to moderate levels is safe and may benefit public health, recent epidemiological studies have controversially reported an increased CVD risk at very low levels of sodium intake $\left(<1500 \mathrm{mg} /\right.$ day). . $2-54^{-5}$ This $\mathrm{J}$-shaped association has predominantly been noted in diabetics and those with pre-existing heart disease. ${ }^{52,54}$ Recent data from the NHANES study indicates intakes greater than $1500 \mathrm{mg}$ sodium per day are likely to be safe for the majority of the population, ${ }^{55}$ 
and this is in line with the magnitude of sodium reduction used in the majority of studies included in this review.

It is worth noting that separate meta-analyses addressing questions around cardiovascular risk reduction and sodium intake are available, but none contain a non-confounded analysis of normotensive participants. Taylor and co-workers ${ }^{56}$ included two trials in the normotensive analysis that recruited individuals with SBP $>140 \mathrm{mmHg}^{26,42}$ in their meta-analysis of longer term RCT's examining overall mortality, cardiovascular mortality and cardiovascular morbidity. Only three truly normotensive trials were included and no findings were presented for overall or cardiovascular mortality, however a reduction in cardiovascular events was reported (RR 0.71, 95\% Cl 0.42, $1.20 \mathrm{p}=$ ). A second metaanalysis by Strazzullo et al. ${ }^{51}$ also included both normotensive and hypertensive participants in a metaanalysis that evaluated dietary sodium intake and cardiovascular events. An increased risk of stroke (RR 1.23, 95\% Cl1.06, $1.43 \mathrm{p}=0.007$ ) and a non-significant trend between dietary sodium and CVD (RR $1.14,95 \% \mathrm{Cl} 0.99,1.32, \mathrm{p}=0.07$ ) was observed, however as with the meta-analysis by Taylor and coworkers it is impossible to determine from this analysis if an increased risk of CVD or stroke would be present in a purely normotensive population with SBP $\leq 140 \mathrm{mmHg}$.

Cardiovascular risk associated with dietary sodium intake is an area in which further long term research is required. In our meta-analysis, four of the five studies included were less than eight weeks duration, ${ }^{10}$, $11,20,34$ and only one trial had a duration greater than a year. ${ }^{12}$ In the context of cardiovascular risk, even trials labelled as long term are too short (i.e. less than six months) to measure outcomes in terms of cardiovascular events.

\section{Potential limitations of this systematic review}

A limitation of this study, like previous meta-analyses, is the lack of longer term trials with large sample numbers. We excluded studies that did not exclude all participants with hypertension as per the definition set by the JNC-7, and supported by the panel members of JNC-8. ${ }^{36,37}$ This resulted in two long term multi-centre trials being excluded.26, 42 These two studies recruited a combined total of 1308 participants assigned to either a sodium reduction or control group, however, five percent of participants had SBP greater than $140 \mathrm{mmHg} .{ }^{47,48}$ The long term effects of these sodium reduction interventions ${ }^{26}$, ${ }^{42}$ were $-1.69 / 0.85 \mathrm{mmHg}$ and $-0.3 / 0.1 \mathrm{mmHg}$, respectively. Another limitation centres on retrieving the appropriate statistical information for dated and large scale multicentre trials. Because we could not be provided with such detail in some instances, trials were excluded. ${ }^{32}$ One trial which had data for subgroups of normotensive populations ${ }^{31}$ could not be included because the statistical data concerning mean and standard deviation for SBP/DBP could not be sourced.

\section{Differences Between the Protocol and the Review}

Additional exclusion criteria were added to ensure the results of the meta-analysis were consistent with the purpose of the review. Trials in pregnant women and trials that intentionally excluded truly normotensive subjects were excluded. JBI MAStARI was originally specified as the pooling software for the meta-analysis, as reported in our protocol, ${ }^{23}$ however MAStARI was not operational at the time, so the review authors elected to use RevMan 5.3.5 consequently to conduct the meta-analysis. Additional sub-analyses were conducted for BMI and study duration, as these were additional study design aspects identified as having the potential to influence outcomes.

\section{Implications for Public Health}

- Current public health recommendations for reducing cardiovascular disease emphasise importance of population sodium reduction as a strategy to reduce blood pressure. The studies included in this review suggest modifying dietary sodium in a seemingly healthy normotensive population is not clinically effective to reduce blood pressure over a period of four months to one year at an individual level (JBI Grade B evidence);

- High sodium intake is linked to a higher risk of stroke, left ventricular hypertrophy, renal impairment, and can impair the arterial vasculature and endothelial function. ${ }^{15,18,19,22,57} \mathrm{~A}$ moderate reduction in dietary sodium, to achieve a sodium intake between $1500-2300 \mathrm{mg}$ per day, may be cardio- 
protective independent of the blood pressure pathway; but this is inconclusive. It also may not be safe to recommend sodium restriction in older adults with diabetes or those with established cardiovascular disease. (JBI Grade B evidence).

- Given the lack of data on very low levels of sodium intake $(<1500 \mathrm{mg} /$ day) in the general population, sodium restriction below this level should not be routinely recommended. (JBI Grade B evidence).

\section{Implications for future research}

Further long term clinical trials in normotensive subgroups are warranted to examine the effects of ethnicity, obesity, pre-hypertension, and diabetes. Recent literature suggests blood pressure reduction should not be overzealous in participants with diabetes, ${ }^{52,58}$ and individuals with hypertension and diabetes should be treated to a minimum blood pressure of $130 \mathrm{mmHg},{ }^{59,60}$ however this should be confirmed by well-designed randomised controlled clinical trials. As it is currently unknown what level of sodium reduction is safe for normotensive diabetics, trials should initially err on the side of caution and restrict sodium to a minimum intake of $1500 \mathrm{mg} /$ day. Dietary sodium restriction also has the potential to exacerbate glucose intolerance, therefore this outcome should be simultaneously examined, along with effects on the renin-angiotensin-aldosterone system.

To better understand dietary sodium intake, true normotensive blood pressure response, and the impact on CVD risk, studies that examine dietary sodium, blood pressure response and cardiovascular risk in participants with SBP equal to or less than $140 \mathrm{mmHg}$ over the longer term (i.e. greater than one year) are required. Randomised controlled trials with long term (greater than four week) duration should also be undertaken to look at other surrogate markers of cardiovascular risk, especially in the absence of longer term clinical trials examining hard outcome measures, which are likely to be logistically difficult, lengthy and very costly to undertake. ${ }^{61}$

\section{Conclusions}

Normotensive participants seemingly free of any renal or cardiovascular impairment are efficient in effectively regulating blood pressure to within $1 \%$ of their baseline SBP values, following a sodium reduction intervention. Blood pressure alone may not be effectively lowered by reducing dietary sodium in normotensive participants, however reducing cardiovascular disease risk may still be of importance. This review confirms that the blood pressure response of normotensive participants with systolic blood pressure less than or equal to $140 \mathrm{mmHg}$ does not significantly change over a period of four weeks or more.

\section{Conflict of Interest}

AT and KD are authors on papers included in this meta-analysis. These authors were not involved in the quality analysis or data extraction of their authored papers.

\section{Acknowledgements}

Many thanks to the authors of the included studies who provided the data relating to normotensive subgroups that was necessary for the extraction of data of some of the variables included in this metaanalysis. To all corresponding authors who were able to provide more detail on all papers retrieved for review, thank you. The review authors wish to thank the peer reviewers whose comments into this manuscript strengthened the review overall.

\section{References}

1. Bromfield S, Muntner P. High Blood Pressure: The Leading Global Burden of Disease Risk Factor and the Need for Worldwide Prevention Programs. Current Hypertension Reports. 2013; 15: 134-6.

2. World Health Organisation. A global brief on Hypertension. Silent killer, global public health crisis. Geneva, Switzerland: 2013. 
3. Centers for Disease Control and Prevention. Getting blood pressure under control: Centers for Disease Control and Prevention; 2012 [updated February 2012]. Available from: http://www.cdc.gov/vitalsigns/hypertension/index.html.

4. National Heart Foundation of Australia. Heart information: Your blood pressure. Australia: National Heart Foundation of Australia; 2008.

5. National Health and Medical Research Council. Australian Dietary Guidelines. Canberra, Australia: National Health and Medical Research Council, 2013.

6. Guyton AC. The surprising kidney-fluid mechanism for pressure control--its infinite gain! Hypertension. 1990; 16: 725-30.

7. Guyton AC. Blood pressure control--special role of the kidneys and body fluids. Science. 1991; 252: 1813-6.

8. Cappuccio FP, Markandu ND, Carney C, Sagnella GA, MacGregor GA. Double-blind randomised trial of modest salt restriction in older people. Lancet. 1997; 350: 850-4.

9. Sacks FM, Svetkey LP, Vollmer WM, et al. Effects on blood pressure of reduced dietary sodium and the Dietary Approaches to Stop Hypertension (DASH) diet. N Engl J Med. 2001; 344: 3-10.

10. Ruppert M, Overlack A, Kolloch R, Kraft K, Göbel B, Stumpe KO. Neurohormonal and metabolic effects of severe and moderate salt restriction in non-obese normotensive adults. $J$ Hypertens. 1993; 11: 743-9.

11. Todd AS, Macginley RJ, Schollum JB, et al. Dietary sodium loading in normotensive healthy volunteers does not increase arterial vascular reactivity or blood pressure. Nephrology. 2012; 17: 249-56.

12. Trials of Hypertension Prevention Collaborative Research Group. Effects of weight loss and sodium reduction intervention on blood pressure and hypertension incidence in overweight people with high-normal blood pressure: the Trials of Hypertension Prevention, phase II. Arch Int Med. 1997; $157: 657$.

13. Graudal NA, Hubeck-Graudal T, Jürgens G. Effects of low-sodium diet vs. high-sodium diet on blood pressure, renin, aldosterone, catecholamines, cholesterol, and triglyceride (Cochrane Review). Am J Hypertens. 2011; 25: 1-15.

14. He FJ, Li J, MacGregor GA. Effect of longer term modest salt reduction on blood pressure: Cochrane systematic review and meta-analysis of randomised trials. BMJ. $2013 ; 346$.

15. Aburto NJ, Ziolkovska A, Hooper L, Elliott P, Cappuccio FP, Meerpohl JJ. Effect of lower sodium intake on health: systematic review and meta-analyses. BMJ. 2013; 346.

16. National Health and Medical Research Council. A review of the evidence to address targeted questions to inform the revision of the Australian Dietary Guidelines Canberra, Australia: Naional Health and Medical Research Council, 2011.

17. Gijsbers L, Dower J, Mensink M, Siebelink E, Bakker S, Geleijnse J. Effects of sodium and potassium supplementation on blood pressure and arterial stiffness: a fully controlled dietary intervention study. J Hum Hypertens. 2015; 29: 592-8.

18. Dickinson KM, Keogh JB, Clifton PM. Effects of a low-salt diet on flow-mediated dilatation in humans. Am J Clin Nutr. 2009; 89: 485-90.

19. Todd AS, MacGinley RJ, Schollum JB, et al. Dietary salt loading impairs arterial vascular reactivity. Am J Clin Nutr. 2010; 91: 557-64.

20. Dickinson KM, Clifton PM, Keogh JB. A reduction of $3 \mathrm{~g} /$ day from a usual $9 \mathrm{~g} /$ day salt diet improves endothelial function and decreases endothelin-1 in a randomised crossover study in normotensive overweight and obese subjects. Atherosclerosis. 2014; 233: 32-8.

21. Dickinson KM, Clifton PM, Keogh JB. Endothelial function is impaired after a high-salt meal in healthy subjects. Am J Clin Nutr. 2011; 93: 500-5.

22. Larson C, Vaidya A, Sun B, Williams J. Influence of dietary sodium modulation on electrocardiographic voltage criteria for left ventricular hypertrophy in normotensive individuals. J Investig Med. 2012; 60: 39-40.

23. Kelly J, Khalesi S, Dickinson K, Hines S, Coombes J, Todd A. The effect of dietary sodium modification on blood pressure in studies of subjects with Systolic Blood Pressure less than $140 \mathrm{mmHg}$ : a systematic review protocol. The JBI Database of Systematic Reviews and Implementation Reports. 2014; 12.

24. Schulz K, Altman D, Moher D, for the CONSORT Group. CONSORT 2010 Statement: updated guidelines for reporting parallel group randomised trials. BMJ. 2010; 340. 
25. Higgins JP, Green S, for The Cochrane Collaboration. Cochrane handbook for systematic reviews of interventions. The Cochrane Collaboration; 2008.

26. Hypertension Prevention Trial Research Group. The Hypertension Prevention Trial: threeyear effects of dietary changes on blood pressure. Arch Int Med. 1990; 150: 153-62.

27. Whelton PK, Kumanyika SK, Cook NR, et al. Efficacy of nonpharmacologic interventions in adults with high-normal blood pressure: results from phase 1 of the Trials of Hypertension Prevention. Trials of Hypertension Prevention Collaborative Research Group. Am J Clin Nutr. 1997; 65: 652S-60S.

28. Nestel PJ, Clifton PM, Noakes M, McArthur R, Howe PR. Enhanced blood pressure response to dietary salt in elderly women, especially those with small waist: hip ratio. $J$ Hypertens. 1993; 11: 1387-94.

29. Takahashi Y, Sasaki S, Okubo S, Hayashi M, Tsugane S. Blood pressure change in a freeliving population-based dietary modification study in Japan. J Hypertens. 2006; 24: 451-8.

30. Zhou X, Liu J-X, Shi R, et al. Compound ion salt, a novel low-sodium salt substitute: from animal study to community-based population trial. Am J Hypertens. 2009; 22: 934-42.

31. Bray GA, Vollmer WM, Sacks FM, Obarzanek E, Svetkey LP, Appel LJ. A further subgroup analysis of the effects of the DASH diet and three dietary sodium levels on blood pressure: results of the DASH-Sodium Trial. Am J Cardiol. 2004; 94: 222-7.

32. Writing Group of the PREMIER Collaborative Research Group. Effects of comprehensive lifestyle modification on blood pressure control. JAMA. 2003; 289: 2083.

33. Santos A, Martins MJ, Guimaraes JT, Severo M, Azevedo I. Sodium-rich carbonated natural mineral water ingestion and blood pressure. Rev Port Cardiol. 2010; 29: 159-72.

34. Flack J, Grimm Jr R, Staffileno B, et al. New salt-sensitivity metrics: variability-adjusted blood pressure change and the urinary sodium-to-creatinine ratio. Ethn Dis. 2001; 12: 10-9.

35. Day S, Altman D. Blinding in clinical trials and other studies. BMJ. 2000; 321: 504.

36. James PA, Oparil S, Carter BL, et al. 2014 evidence-based guideline for the management of high blood pressure in adults: Report from the panel members appointed to the eighth joint national committee (jnc 8). JAMA. 2014; 311: 507-20.

37. Chobanian AV, Bakris GL, Black HR, et al. Seventh report of the joint national committee on prevention, detection, evaluation, and treatment of high blood pressure. Hypertension. 2003; 42: $1206-52$.

38. Cobiac L, Nestel PJ, Wing LM, Howe PR. A low-sodium diet supplemented with fish oil lowers blood pressure in the elderly. $J$ Hypertens. 1992; 10: 87-92.

39. Mascioli S, Grimm R, Launer C, et al. Sodium chloride raises blood pressure in normotensive subjects. The study of sodium and blood pressure. Hypertension. 1991; 17: 121.

40. Puska P, lacono JM, Nissinen A, et al. Controlled, randomised trial of the effect of dietary fat on blood pressure. Lancet. 1983; 1: 1-5.

41. Watt G, Foy C, Hart J, et al. Dietary sodium and arterial blood pressure: evidence against genetic susceptibility. BMJ. 1985; 291: 1525.

42. Whelton PK, Appel L, Charleston J, et al. The effects of nonpharmacologic interventions on blood pressure of persons with high normal levels: results of the Trials of Hypertension Prevention, phase I. JAMA. 1992; 267: 1213-20.

43. Stamler R, Stamler J, Gosch FC, et al. Primary prevention of hypertension by nutritionalhygienic means. Final report of a randomized, controlled trial. JAMA. 1989; 262: 1801-7.

44. Lim H, Lip G. Arterial stiffness: beyond pulse wave velocity and its measurement. J Hum Hypertens. 2008; 22: 656-8.

45. Avolio AP, Clyde KM, Beard TC, Cooke HM, Ho K, O'Rourke MF. Improved arterial distensibility in normotensive subjects on a low salt diet. Arterioscler Thromb Vasc Biol. 1986; 6: $166-9$.

46. du Cailar G, Mimran A, Fesler P, Ribstein J, Blacher J, Safar ME. Dietary sodium and pulse pressure in normotensive and essential hypertensive subjects. J Hypertens. 2004; 22: 697703.

47. Hooper L, Bartlett C, Davey SG, Ebrahim S. Advice to reduce dietary salt for prevention of cardiovascular disease. Cochrane Database Systematic Reviews. 2004; 1.

48. Elliott P, Stamler J, Nichols R, et al. Intersalt revisited: further analyses of 24 hour sodium excretion and blood pressure within and across populations. BMJ. 1996; 312: 1249-53. 
49. Franklin SS, Gustin W, Wong ND, et al. Hemodynamic patterns of age-related changes in blood pressure The Framingham Heart Study. Circulation. 1997; 96: 308-15.

50. Intersalt Collaborative Research Group. Intersalt: an international study of electrolyte excretion and blood pressure. Results for 24 hour urinary sodium and potassium excretion. Intersalt Cooperative Research Group. BMJ. 1988; 297: 319-28.

51. Strazzullo P, D'Elia L, Kandala NB, Cappuccio FP. Salt intake, stroke, and cardiovascular disease: meta-analysis of prospective studies. BMJ. 2009; 339: b4567.

52. Bangalore S, Messerli FH, Wun C-C, et al. J-curve revisited: an analysis of blood pressure and cardiovascular events in the Treating to New Targets (TNT) Trial. Eur Heart J. 2010; 31: 2897-908.

53. O'Donnell M, Mente A, Rangarajan S, et al. Urinary sodium and potassium excretion, mortality, and cardiovascular events. N Engl J Med. 2014; 371: 612-23.

54. O'Donnell MJ, Yusuf S, Mente A, et al. Urinary sodium and potassium excretion and risk of cardiovascular events. JAMA. 2011; 306: 2229-38.

55. Cohen HW, Hailpern SM, Fang J, Alderman MH. Sodium intake and mortality in the NHANES II follow-up study. Am J Med. 2006; 119: 275.e7-14.

56. Taylor RS, Ashton KE, Moxham T, Hooper L, Ebrahim S. Reduced dietary salt for the prevention of cardiovascular disease: a meta-analysis of randomized controlled trials (Cochrane review). Am J Hypertens. 2011; 24: 843-53.

57. Krekels M, Kroon A, de Leeuw P. Sodium intake as a modulator of kidney function. Curr Hypertens Rev. 2015; epub ahead of print.

58. Cushman WC, Evans GW, Byington RP, et al. Effects of intensive blood-pressure control in type 2 diabetes mellitus. N Engl J Med. 2010; 362: 1575.

59. DiNicolantonio JJ, Niazi AK, Sadaf R, O' Keefe JH, Lucan SC, Lavie CJ. Dietary Sodium Restriction: Take It with a Grain of Salt. Am J Med. 2013; 126: 951-5.

60. Ekinci El, Clarke S, Thomas MC, et al. Dietary salt intake and mortality in patients with type 2 diabetes. Diabetes Care. 2011; 34: 703-9.

61. Ames RP. The effect of sodium supplementation on glucose tolerance and insulin concentrations in patients with hypertension and diabetes mellitus. Am J Hypertens. 2001; 14: 653-9. 


\section{Appendix I: Search strategy}

\section{MEDLINE (via Pubmed)}

The following key words were used (03/03/2014) in the combination

\begin{tabular}{|l|l|}
\hline Search & Query \\
\hline$\# 1$ & salt \\
\hline$\# 2$ & sodium \\
\hline$\# 3$ & 1 OR 2 \\
\hline$\# 5$ & normotens ${ }^{*}$ \\
\hline$\# 6$ & Dormal AND blood pressure) \\
\hline$\# 7$ & 4 OR 5 OR 6 \\
\hline$\# 8$ & blood pressure \\
\hline$\# 9$ & pulse wave \\
\hline$\# 10$ & endothelial function \\
\hline$\# 11$ & flow mediated \\
\hline$\# 12$ & 8 OR 9 OR 10 OR 11 \\
\hline$\# 13$ & randomi* \\
\hline
\end{tabular}




\section{Appendix II \\ MAStARI Appraisal instrument}

\section{JBI Critical Appraisal Checklist for Randomised Control / Pseudo-randomised Trial}

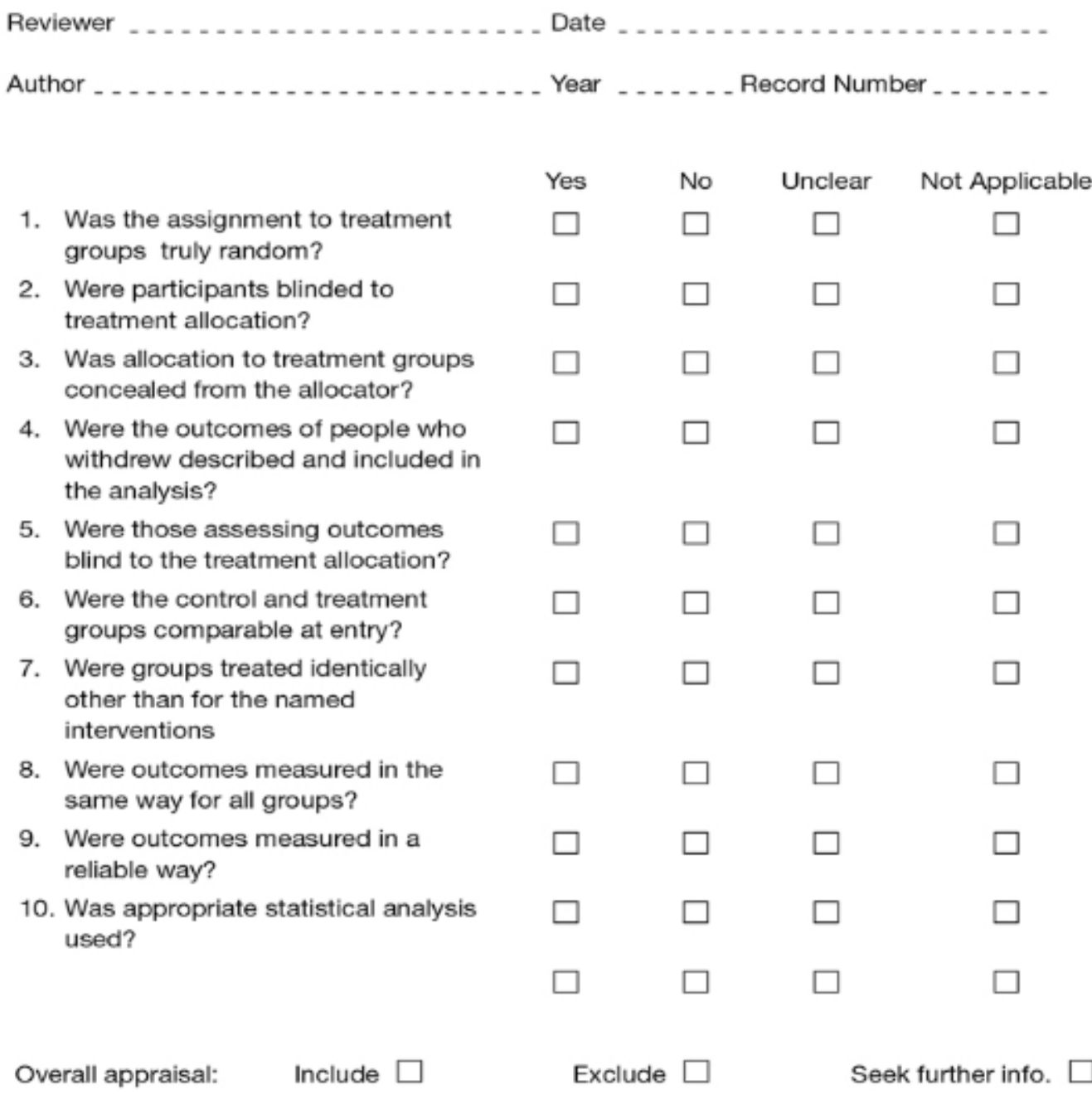




\section{Appendix III \\ MAStARI data extraction instrument}

\section{JBI Data Extraction Form for Experimental / Observational Studies}

\begin{tabular}{|c|c|c|c|c|c|}
\hline \multicolumn{6}{|l|}{ Reviewer } \\
\hline \multicolumn{6}{|c|}{ Author $\ldots$} \\
\hline \multicolumn{6}{|c|}{ 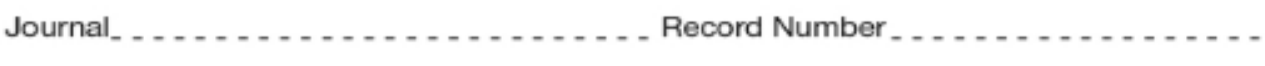 } \\
\hline \multicolumn{6}{|c|}{ Study Method } \\
\hline RCT & $\square$ & Quasi-RCT & $\square$ & Longitudinal & $\square$ \\
\hline Retrospective & $\square$ & Observational & $\square$ & Other & $\square$ \\
\hline
\end{tabular}

Participants

Setting

Population

\section{Sample size}

Group A

Group B

\section{Interventions}

Intervention A

Intervention B

Authors Conclusions:

Reviewers Conclusions: 


\section{Appendix IV: Table of included studies}

\section{Table 3: Table of included studies}

MASTARI

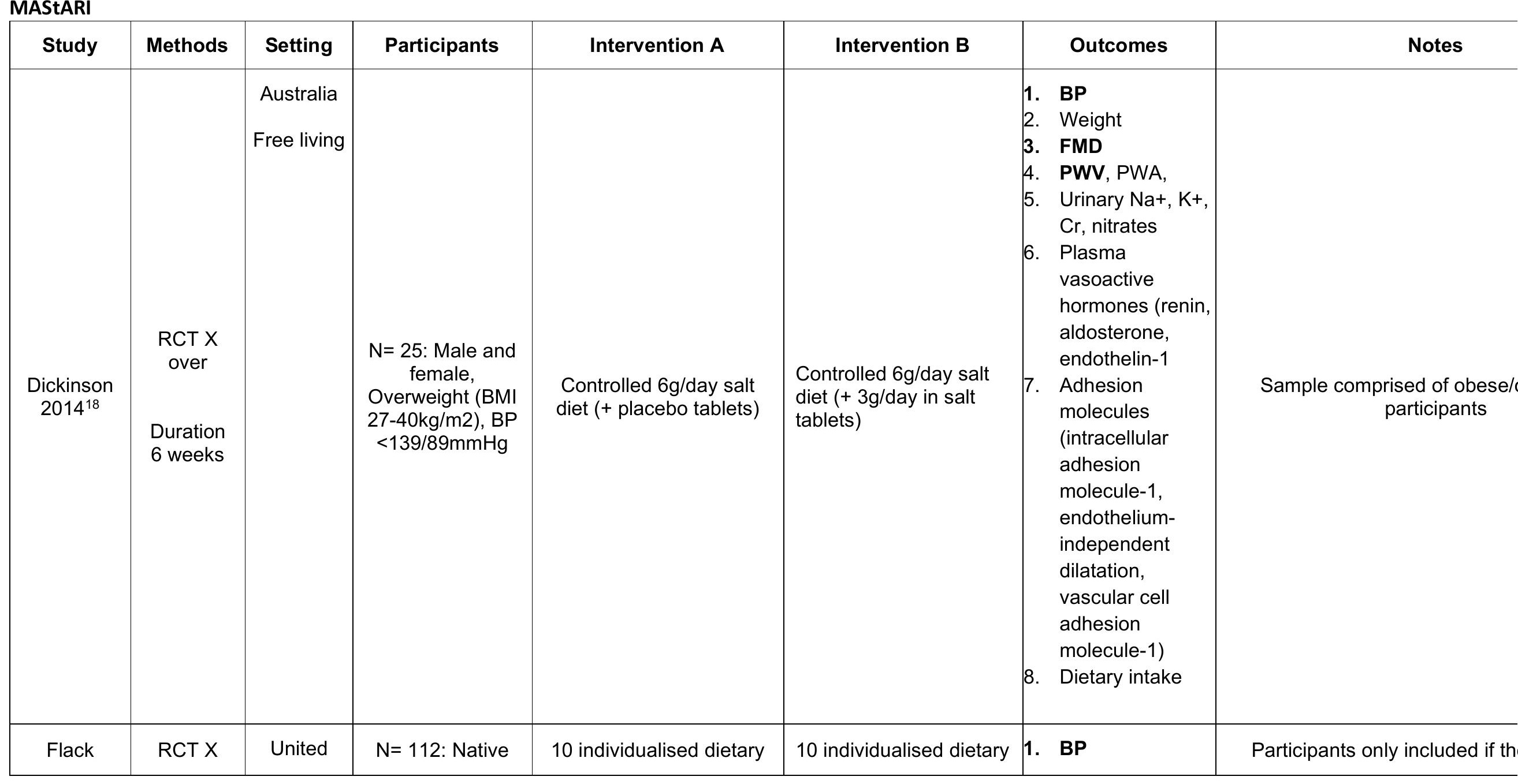




\begin{tabular}{|c|c|c|c|c|c|c|c|}
\hline Study & Methods & Setting & Participants & Intervention A & Intervention B & Outcomes & Notes \\
\hline $2001^{34}$ & $\begin{array}{l}\text { over } \\
\text { Duration } \\
8 \text { weeks }\end{array}$ & $\begin{array}{c}\text { States } \\
\text { Free living }\end{array}$ & $\begin{array}{c}\text { African-American } \\
\text { males and } \\
\text { females, } \\
\text { compliant to } \\
\text { urinary Na+ } \\
\text { restriction } \\
<140 \mathrm{mmol} / \mathrm{L} / \text { day, } \\
\mathrm{BP} \\
<140 / 89 \mathrm{mmHg}, \\
\text { fasting glucose } \\
<7.7 \mathrm{mmol} / \mathrm{L}\end{array}$ & $\begin{array}{c}\text { counselling sessions }+1- \\
2 \text { if required }- \text { aimed for } \\
\text { a target sodium intake of } \\
75-80 \text { mmol/day }+ \text { sodium } \\
\text { tablets }\end{array}$ & $\begin{array}{l}\text { counselling sessions }+ \\
1-2 \text { if required - aimed } \\
\text { for a target sodium } \\
\text { intake of } 75- \\
80 \mathrm{mmol} / \text { day }+ \text { placebo } \\
\text { tablets }\end{array}$ & 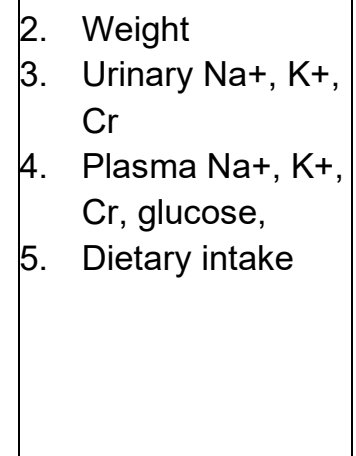 & $\begin{array}{r}<140 \mathrm{mmol} / \text { day in the eligibil } \\
\text { Compliance to intervention th } \\
\text { histories and pill cour }\end{array}$ \\
\hline $\begin{array}{l}\text { Ruppert } \\
1993^{10}\end{array}$ & $\begin{array}{l}\text { RCT X } \\
\text { over } \\
\text { Duration } \\
4 \text { weeks }\end{array}$ & \begin{tabular}{|} 
Germany \\
Free living \\
studied in \\
hospital last \\
day of each \\
intervention
\end{tabular} & $\begin{array}{c}\mathrm{N}=25 \text { (6 salt } \\
\text { sensitive, } 19 \text { salt } \\
\text { resistant), Male } \\
\text { and female aged } \\
20-65 \text { years, BP } \\
<140 / 90, \\
\text { BMl<30kg/m }\end{array}$ & $\begin{array}{l}\text { Standardised diet } \\
85 \mathrm{mmol} \text { sodium for four } \\
\text { weeks }\end{array}$ & $\begin{array}{l}\text { Standardised diet } \\
200 \mathrm{mmol} \text { sodium for } \\
\text { four weeks }\end{array}$ & \begin{tabular}{|ll} 
1. & BP \\
2. & Plasma $\mathrm{Na}+, \mathrm{K}+$ \\
3. & Lipid profiles \\
& (TG, LDL, HDL, \\
& TC) \\
4. & Plasma \\
& hormones (renin \\
& and \\
& noradrenaline)
\end{tabular} & $\begin{array}{l}\text { Salt resistant individuals do no } \\
\text { great falls in blood pressure folld } \\
\text { reduction, compared to salt se } \\
\text { sample is unevenly represen } \\
\text { resistant participant }\end{array}$ \\
\hline $\begin{array}{c}\text { Todd } \\
2012^{11}\end{array}$ & $\begin{array}{l}\text { RCT X } \\
\text { over } \\
\text { Duration } \\
4 \text { weeks }\end{array}$ & $\begin{array}{l}\text { New } \\
\text { Zealand } \\
\text { Free living }\end{array}$ & $\begin{array}{c}\mathrm{N}=23: \text { Male and } \\
\text { female aged } 20- \\
65 \text { years, BP } \\
<130 / 85, \\
\text { BMI<30kg/m², no } \\
\text { clinical } \\
\text { signs/diagnosis } \\
\text { CVD, renal } \\
\text { insufficiency, or } \\
\text { diabetes }\end{array}$ & $\begin{array}{l}\text { Low salt ( } 60 \mathrm{mmol} / \mathrm{day}) \\
\text { diet consumed by all } \\
\text { participants - in addition } \\
\text { consuming a high salt } \\
(200-250 \mathrm{mmol} \mathrm{Na}) \\
\text { tomato juice for } 4 \text { weeks. }\end{array}$ & $\begin{array}{l}\text { Low salt }(60 \mathrm{mmol} / \mathrm{day}) \\
\text { diet consumed by all } \\
\text { participants }- \text { in } \\
\text { addition consuming a } \\
\text { no added salt tomato } \\
\text { juice }(0 \mathrm{mmol} \mathrm{Na}) \text { for } 4 \\
\text { weeks }\end{array}$ & \begin{tabular}{|ll} 
1. & BP \\
2. & Weight \\
3. & PWV, PWA, \\
4. & Urinary $\mathrm{Na}+, \mathrm{K}+$, \\
& Cr, nitrates \\
5. & Plasma \\
& vasoactive \\
& hormones (renin, \\
& aldosterone, \\
& endothelin-1, \\
& insulin, atrial \\
& natriuretic
\end{tabular} & $\begin{array}{r}\text { Compliance to intervention th } \\
\text { histories and spot urine ar } \\
4 \text { participants dropped out, only } \\
\text { the high salt interventi }\end{array}$ \\
\hline
\end{tabular}




\begin{tabular}{|c|c|c|c|c|c|c|c|c|}
\hline Study & Methods & Setting & Participants & Intervention A & Intervention B & & Outcomes & Notes \\
\hline & & & & & & 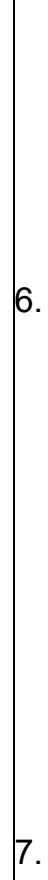 & $\begin{array}{l}\text { peptide, C- } \\
\text { natriuretic } \\
\text { peptide and N- } \\
\text { terminal C- } \\
\text { natriuretic } \\
\text { peptide } \\
\text { Markers of } \\
\text { oxidative stress } \\
\text { and inflammation } \\
\text { (nitrate and } \\
\text { nitrite } \\
\text { concentrations, } \\
\text { lipid peroxides,7 } \\
\text { lipofuscin-like } \\
\text { fluorophores } \\
\text { (LF),8 high- } \\
\text { sensitivity C- } \\
\text { reactive protein } \\
\text { Dietary intake }\end{array}$ & \\
\hline $\begin{array}{l}\text { TOHP II } \\
1997^{12}\end{array}$ & $\begin{array}{c}\text { RCT } \\
\text { Parallel } \\
\\
\text { Duration } \\
36 \\
\text { months }\end{array}$ & $\begin{array}{l}\text { United } \\
\text { States - } \\
\text { multi-centre } \\
\text { Free living }\end{array}$ & $\begin{array}{l}\text { Sodium } \\
\text { reduction }-\mathrm{n}= \\
515 \\
\text { Control }-\mathrm{n}=514 \\
\text { Male and female } \\
\text { aged } 30-54 \\
\text { years, } \\
\text { overweight (BMI } \\
24.4-37.4 \mathrm{~kg} / \mathrm{m} 2) \text {, } \\
\mathrm{BP}<139 / 89, \mathrm{no} \\
\text { clinical }\end{array}$ & $\begin{array}{l}\text { Sodium reduction group } \\
\text { (target } 80 \mathrm{mmol} / \text { day) }\end{array}$ & $\begin{array}{l}\text { Control group (no } \\
\text { advice) }\end{array}$ & & $\begin{array}{l}\text { BP } \\
\text { Weight } \\
\text { Urinary } \mathrm{Na}+, \mathrm{K}+\text {, } \\
\mathrm{Cr} \\
\text { Dietary intake }\end{array}$ & $\begin{array}{r}\text { Large blood pressure changes n } \\
\text { in initial } 6 \text { months. Over } 36 n \\
\text { changes were less prono }\end{array}$ \\
\hline
\end{tabular}




\begin{tabular}{|c|c|c|l|l|l|l|l|}
\hline Study & Methods & Setting & Participants & Intervention A & Intervention B & Outcomes & Notes \\
\hline & & & $\begin{array}{l}\text { signs/diagnosis } \\
\text { CVD, renal } \\
\text { insufficiency, or } \\
\text { diabetes }\end{array}$ & & & & \\
\hline
\end{tabular}




\section{Appendix V: Excluded studies}

Adeyemo AA, Prewitt TE, Luke A, Omotade OO, Rotimi CN, Brieger WR, et al. The feasibility of implementing a dietary sodium reduction intervention among free-living normotensive individuals in south west Nigeria. Ethnicity \& disease. 2002;12(2):207-12.

Reason for exIcusion: Recruited above 140mmHg $(<160 \mathrm{mmHg})$

Allen AR, Gullixson LR, Wolhart SC, Kost SL, Schroeder DR, Eisenach JH. Dietary sodium influences the effect of mental stress on heart rate variability: a randomized trial in healthy adults. J Hypertens. 2014;32(2):374-82.

Reason for exclusion: Study duration less than 4 weeks

Aro A, Pietinen P, Valsta LM, Salminen I, Turpeinen AM, Virtanen M, et al. Lack of effect on blood pressure by low fat diets with different fatty acid compositions. J Hum Hypertens. 1998;12(6):383-9.

Reason for exclusion: No intervention of interest

Australian National Health \& Medical Research Council Dietary Salt Study Management Committee. Fall in blood pressure with modest reduction in dietary salt intake in mild hypertension. Lancet. 1989;1(8635):399-402.

Reason for exclusion: Studies on hypertensives

Australian National Health \& Medical Research Council Dietary Salt Study Management Committee. Effects of replacing sodium intake in subjects on a low sodium diet: a crossover study. Clin Exp Hypertens. 1989;11(5-6):1011-24.

Reason for exclusion: Recruited above $140 \mathrm{mmHg}$

Azizi M, Linhart A, Alexander J, Goldberg A, Menten J, Sweet C, et al. Pilot study of combined blockade of the renin-angiotensin system in essential hypertensive patients. J Hypertens. 2000;18(8):1139-47.

Reason for exclusion: Studies on hypertensives

Barba G, Vallance PJ, Strazzullo P, MacAllister RJ. Effects of sodium intake on the pressor and renal responses to nitric oxide synthesis inhibition in normotensive individuals with different sodium sensitivity. J Hypertens. 2000;18(5):615-21.

Reason for exclusion: Study duration less than 4 weeks

Barri YM, Wilcox CS. Salt intake determines the renal response to L-arginine infusion in normal human subjects. Kidney Int. 1998;53(5):1299-304.

Reason for exclusion: Study duration less than 4 weeks

Beerendonk CC, Derkx FH, Schellekens AP, Hop WC, van Dop PA. The influence of dietary sodium restriction on renal and ovarian renin and prorenin production during ovarian stimulation. Hum Reprod. 1996;11(5):956-61.

Reason for exclusion: Study groups not comparable - low sodium group started intervention 10 days before control group.

Benetos A, Xiao YY, Cuche JL, Hannaert P, Safar M. Arterial effects of salt restriction in hypertensive patients. A 9-week, randomized, double-blind, crossover study. J Hypertens. 1992;10(4):355-60.

Reason for exclusion: Studies on hypertensives

Blumenthal JA, Babyak MA, Hinderliter A, Watkins LL, Craighead L, Lin PH, et al. Effects of the DASH diet alone and in combination with exercise and weight loss on blood pressure and cardiovascular biomarkers in men and women with high blood pressure: the ENCORE study. Arch Intern Med. 2010;170(2):126-35.

Reason for exclusion: Recruited above $140 \mathrm{mmHg}(<159 \mathrm{mmHg})$ 
Bompiani GD, Cerasola G, Morici ML, Condorelli M, Trimarco B, De Luca N, et al. Effects of moderate low sodium/high potassium diet on essential hypertension: results of a comparative study. Int J Clin Pharmacol Ther Toxicol. 1988;26(3):129-32.

Reason for exclusion: Studies on hypertensives

Bray GA, Vollmer WM, Sacks FM, Obarzanek E, Svetkey LP, \& Appel LJ. A further subgroup analysis of the effects of the DASH diet and three dietary sodium levels on blood pressure: results of the DASH-Sodium Trial. Am J Cardiol, 2004; 94(2): 222-227.

Reason for exclusion: Population not considered suitable for the assessment of the primary outcome as subjects with SBP $<120 \mathrm{mmHg}$ were excluded. Pre-hypertensive subjects display a heightened response to sodium.

Brier ME, Luft FC. Sodium kinetics in white and black normotensive subjects: possible relevance to salt-sensitive hypertension. Am J Med Sci. 1994;307(Suppl 1):S38-42.

Reason for exclusion: Study duration less than 4 weeks

Buckley MG, Markandu ND, Sagnella GA, MacGregor GA. Brain and atrial natriuretic peptides: a dual peptide system of potential importance in sodium balance and blood pressure regulation in patients with essential hypertension. J Hypertens. 1994;12(7):809-13.

Reason for exclusion: No Sodium intervention; Study duration less than 4 weeks

Bunke M, Gleason JR, Jr., Brier M, Sloan R. Effect of erythropoietin on renal excretion of a sodium load. Clin Pharmacol Ther. 1994;55(5):563-8.

Reason for exclusion: No intervention of interest

Butscher K, Jamali S, Talib R, Ravussin P, Poggi-Bach J, Ecoffey C. [Effects of different loading solutions on plasma osmolality]. Annales francaises d'anesthesie et de reanimation. 1996;15(7):1037-40.

Reason for exclusion: No intervention of interest

Calabrese EJ, Tuthill RW. The Massachusetts Blood Pressure Study, Part 3. Experimental reduction of sodium in drinking water: effects on blood pressure. Toxicol Ind Health. 1985;1(1):19-34.

Reason for exclusion: Studies in paediatrics

Capaldo B, Guardasole V, Pardo F, Matarazzo M, Di Rella F, Numis F, et al. Abnormal vascular reactivity in growth hormone deficiency. Circulation. 2001;103(4):520-4.

Reason for exclusion: No intervention of interest

Cappuccio FP, Kerry SM, Micah FB, Plange-Rhule J, Eastwood JB. A community programme to reduce salt intake and blood pressure in Ghana. BMC Public Health. 2006;6(1):13.

Reason for exclusion: No intervention of interest

Cappuccio FP, Markandu ND, Beynon GW, Shore AC, MacGregor GA. Effect of increasing calcium intake on urinary sodium excretion in normotensive subjects. Clin Sci. 1986;71(4):453-6. Reason for exclusion: Recruited above $140 \mathrm{mmHg}$

Cappuccio FP, Markandu ND, Carney C, Sagnella GA, MacGregor GA. Double-blind randomised trial of modest salt restriction in older people. Lancet. 1997;350(9081):850-4.

Reason for exclusion: Studies included on hypertensives

Carney SL, Gillies AH, Smith AJ, Smitham S. Increased dietary sodium chloride in patients treated with antihypertensive drugs. Clin Exp Hypertens. 1991;13(3):401-7.

Reason for exclusion: Studies included on hypertensives

Chalmers J, Morgan T, Doyle A, Dickson B, Hopper J, Mathews J, et al. Australian National Health and Medical Research Council dietary salt study in mild hypertension. J Hypertens. 1986 
Dec;4(6):S629-37.

Reason for exclusion: Studies included on hypertensives

Chin-Dusting JP, Alexander CT, Arnold PJ, Hodgson WC, Lux AS, Jennings GL. Effects of in vivo and in vitro L-arginine supplementation on healthy human vessels. Journal of cardiovascular pharmacology. 1996;28(1):158-66.

Reason for exclusion: No intervention of interest

Chopra A, Kumar V, Dutta A. Hypertonic versus normal saline as initial fluid bolus in pediatric septic shock. Indian journal of pediatrics. 2011;78(7):833-7.

Reason for exclusion: Studies in paediatrics

Closas J, Genest J, Larochelle P, Cusson J, Gutkowska J, Hamet P, et al. [Effects of phenylephrine on atrial natriuretic factor and the renin-aldosterone axis in normal patients and essential hypertensive patients]. Archives des maladies du coeur et des vaisseaux. 1988;81:75-8. Reason for exclusion: No Sodium intervention; Blood pressure not measured

Conlin PR. The dietary approaches to stop hypertension (DASH) clinical trial: implications for lifestyle modifications in the treatment of hypertensive patients. Cardiology in Review. 1999;7(5):2848.

Reason for exclusion: Reanalysis study

Cook NR, Cohen J, Hebert PR, Taylor JO, Hennekens CH. Implications of small reductions in diastolic blood pressure for primary prevention. Arch Intern Med. 1995;155(7):701-9.

Reason for exclusion: Observational Study

Cooper JN, Tepper P, Barinas-Mitchell E, Woodard GA, Sutton-Tyrrell K. Serum aldosterone is associated with inflammation and aortic stiffness in normotensive overweight and obese young adults. Clin Exp Hypertens. 2012;34(1):63-70.

Reason for exclusion: Not an RCT (Cross sectional)

Cooper R, Van Horn L, Liu K, Trevisan M, Nanas S, Ueshima H, et al. A randomized trial on the effect of decreased dietary sodium intake on blood pressure in adolescents. J Hypertens. 1984 Aug;2(4):361-6.

Reason for exclusion: Study on adolescents (24 day study)

Costa FV, Ambrosioni E, Montebugnoli L, Paccaloni L, Vasconi L, Magnani B. Effects of a low-salt diet and of acute salt loading on blood pressure and intralymphocytic sodium concentration in young subjects with borderline hypertension. Clin Sci. 1981;61 Suppl 7:21s-3s.

Reason for exclusion: Studies on hypertensives

Creager MA, Roddy MA, Holland KM, Hirsch AT, Dzau VJ. Sodium depresses arterial baroreceptor reflex function in normotensive humans. Hypertension. 1991;17(6 Pt 2):989-96.

Reason for exclusion: Study duration less than 4 weeks

Cuneo RC, Espiner EA, Nicholls MG, Yandle TG, Livesey JH. Effect of physiological levels of atrial natriuretic peptide on hormone secretion: inhibition of angiotensin-induced aldosterone secretion and renin release in normal man. J Clin Endocrinol Metab. 1987;65(4):765-72. Reason for exclusion: Concomitant venous infusion

Damasceno A, Caupers P, Santos A, Lobo E, Sevene E, Bicho M, et al. Influence of salt intake on the daytime-nighttime blood pressure variation in normotensive and hypertensive black subjects. Revista portuguesa de cardiologia. 2000;19(3):315-29.

Reason for exclusion: Study duration less than 4 weeks

Damasceno A, Santos A, Pestana M, Serrao P, Caupers P, Soares-da-Silva P, et al. Acute hypotensive,natriuretic, and hormonal effects of nifedipine in salt-sensitive and salt-resistant black normotensive and hypertensive subjects. J Cardiovasc Pharmacol. 1999;34(3):346-53. Reason for exclusion: Study duration less than 4 weeks 
Damasceno A, Santos A, Serrao P, Caupers P, Soares-da-Silva P, Polonia J. Deficiency of renal dopaminergic-dependent natriuretic response to acute sodium load in black salt-sensitive subjects in contrast to salt-resistant subjects. J Hypertens. 1999;17(12 Pt 2):1995-2001.

Reason for exclusion: Study duration less than 4 weeks

Del Rio A, Rodriguez-Villamil JL. Metabolic effects of strict salt restriction in essential hypertensive patients. J Intern Med. 1993;233(5):409-14.

Reason for exclusion: Not an RCT (Cross sectional)

Diaz KM, Muntner P, Levitan EB, Brown MD, Babbitt DM, Shimbo D. The effects of weight loss and salt reduction on visit-to-visit blood pressure variability: results from a multicenter randomized controlled trial. J Hypertens. 2014;32(12):840-848.

Reason for exclusion: Studies on hypertensives

Dickinson KM, Clifton PM, Burrell LM, Barrett PH, Keogh JB. Postprandial effects of a high salt meal on serum sodium, arterial stiffness, markers of nitric oxide production and markers of endothelial function. Atherosclerosis. 2014;232(1):211-6.

Reason for exclusion: Reanalysis Study (of TOHP II)

Dickinson KM, Keogh JB, Clifton PM. Effects of a low-salt diet on flow-mediated dilatation in humans. Am J Clin Nutr. 2009;89(2):485-90.

Reason for exclusion: Study duration less than 4 weeks

Dishy V, Sofowora GG, Imamura H, Nishimi Y, Xie HG, Wood AJ, et al. Nitric oxide production decreases after salt loading but is not related to blood pressure changes or nitric oxidemediated vascular responses. J Hypertens. 2003;21(1):153-7.

Reason for exclusion: Study duration less than 4 weeks

Dodson PM, Stephenson J, Dodson LJ, Kurnik D, Kritzinger EE, Taylor KG, et al. Randomised blind controlled trial of a high fibre, low fat and low sodium dietary regimen in mild essential hypertension. J Hum Hypertens. 1989;3(3):197-202.

Reason for exclusion: Studies on hypertensives

Dorough AE, Winett RA, Anderson ES, Davy BM, Martin EC, \& Hedrick V. DASH to wellness: Emphasizing self-regulation through E-health in adults with prehypertension. Health Psychol, 2014:33(3):249-254.

Reason for exclusion: Concomitant intervention

Duarte JD, Zineh I, Burkley B, Gong Y, Langaee TY, Turner ST, et al. Effects of genetic variation in H3K79 methylation regulatory genes on clinical blood pressure and blood pressure response to hydrochlorothiazide. J Transl Med. 2012;10:56.

Reason for exclusion: Studies on hypertensives

Fagerberg B, Andersson OK, Isaksson B, Bjorntorp P. Blood pressure control during weight reduction in obese hypertensive men: separate effects of sodium and energy restriction. BMJ. 1984;288(6410):11-4.

Reason for exclusion: Studies on hypertensives

Farquharson CA, Struthers AD. Aldosterone induces acute endothelial dysfunction in vivo in humans: evidence for an aldosterone-induced vasculopathy. Clin Sci. 2002;103(4):425-31.

Reason for exclusion: No intervention of interest

Fauvel JP, Najem R, Ryon B, Ducher M, Laville M. Effects of rilmenidine on stress-induced peak blood pressure and renal function. J Cardiovasc Pharmacol. 1999;34(1):41-5.

Reason for exclusion: No intervention of interest 
Feldman RD, Logan AG, Schmidt ND. Dietary salt restriction increases vascular insulin resistance. Clin Pharmacol Ther. 1996;60(4):444-51.

Reason for exclusion: Study duration less than 4 weeks

Ferrari P, Gadient G, Cozzio A, Shaw S, Weidmann P. Reduced plasma cyclic GMP but normal renal responses to atrial natriuretic factor in pre-hypertension. Blood Pressure. 1996;5(1):16-26.

Reason for exclusion: No Sodium intervention; Study duration less than 4 weeks

Ferri C, Bellini C, Carlomagno A, Perrone A, Santucci A. Urinary kallikrein and salt sensitivity in essential hypertensive males. Kidney Int. 1994;46(3):780-8.

Reason for exclusion: Studies on hypertensives; Study duration less than 4 weeks

Ferri C, Bellini C, Desideri G, Di Francesco L, De Mattia G, Santucci A, et al. Salt-sensitivity is associated with a hyperinsulinaemic and hyperglycaemic response to atrial natriuretic peptide infusion in human essential hypertension. Diabetologia. 1994;37(3):308-12.

Reason for exclusion: No intervention of interest

Ferri C, Di Francesco L, Baldoncini R, Bellini C, Desideri G, Carlomagno A, et al. Sodium-modulating hormones and the pressor response to sodium chloride in essential arterial hypertension. Annali italiani di medicina interna. 1993;8(2):89-94.

Reason for exclusion: Studies on hypertensives; Study duration less than 4 weeks

Fodor JG, Whitmore B, Leenen F, Larochelle P. Lifestyle modifications to prevent and control hypertension. 5. Recommendations on dietary salt. Canadian Hypertension Society, Canadian Coalition for High Blood Pressure Prevention and Control, Laboratory Centre for Disease Control at Health Canada, Heart and Stroke Foundation of Canada. CMAJ. 1999;160(9 Suppl):S29-34.

Reason for exclusion: Not an RCT (Review)

Foo M, Denver AE, Coppack SW, Yudkin JS. Effect of salt-loading on blood pressure, insulin sensitivity and limb blood flow in normal subjects. Clin Sci. 1998;95(2):157-64.

Reason for exclusion: Study duration less than 4 weeks

Forrester T, Adeyemo A, Soarres-Wynter S, Sargent L, Bennett F, Wilks R, et al. A randomized trial on sodium reduction in two developing countries. J Hum Hypertens. 2005;19(1):55-60.

Reason for exclusion: Study duration less than 4 weeks (3 weeks)

Fotherby MD, Potter JF. Effects of moderate sodium restriction on clinic and twenty-four-hour ambulatory blood pressure in elderly hypertensive subjects. J Hypertens. 1993;11(6):657-63. Reason for exclusion: Studies on hypertensives

Fuchs FD, Wannmacher CM, Wannmacher L, Guimaraes FS, Rosito GA, Gastaldo G, et al. Effect of sodium intake on blood pressure, serum levels and renal excretion of sodium and potassium in normotensives with and without familial predisposition to hypertension. Brazi J Med Biol Res.1987;20(1):25-34.

Reason for exclusion: Study duration less than 4 weeks

Galley HF, Thornton J, Howdle PD, Walker BE, Webster NR. Combination oral antioxidant supplementation reduces blood pressure. Clin Sci. 1997;92(4):361-5.

Reason for exclusion: No intervention of interest

Garcia-Pena C, Thorogood M, Armstrong B, Reyes-Frausto S, Munoz O. Pragmatic randomized trial of home visits by a nurse to elderly people with hypertension in Mexico. Int $\mathrm{J}$ Epidemiol. 2001;30(6):1485-91.

Reason for exclusion: Studies on hypertensives

Garg SK, Gupta U, Mathur VS. Comparative bioequivalence study of furosemide in human volunteers. Int J Clin Pharmacol Ther Toxicol. 1984;22(11):618-20.

Reason for exclusion: Participants on antihypertensive medications 
Gates PE, Tanaka H, Hiatt WR, Seals DR. Dietary sodium restriction rapidly improves large elastic artery compliance in older adults with systolic hypertension. Hypertension. 2004;44(1):35-41. Reason for exclusion: Recruited above $140 \mathrm{mmHg}$ (indicated from baseline measurement)

Georg Jensen M, Kristensen M, Belza A, Knudsen JC, Astrup A. Acute effect of alginate-based preload on satiety feelings, energy intake, and gastric emptying rate in healthy subjects. Obesity. 2012;20(9):1851-8.

Reason for exclusion: No intervention of interest

Gijsbers L, Dower JI, Mensink M, Siebelink E, Bakker SJL, \& Geleijnse JM. Effects of sodium and potassium supplementation on blood pressure and arterial stiffness: a fully controlled dietary intervention study. J Hum Hypertens 2015; epub ahead of print.

Reason for exclusion: Concomitant intervention (Potassium supplement)

Glanzer K, Schlebusch H, Sorger M, Pannenbecker D, Kruck F. Influence of intravenous Mg++ solutions on renal excretion of potassium, sodium, calcium, chloride, intraleukocytic potassium and peripheral vascular resistance: a metabolic and hemodynamic study in normal volunteers. Magnesium. 1984;3(4-6):324-38.

Reason for exclusion: Study duration less than 4 weeks

Gogtay NJ, Dalvi SS, Mhatre RB, Kirodian BG, Gupta AH, Jadhav SP, et al. A randomized, crossover, assessor-blind study of the bioequivalence of a single oral dose of $200 \mathrm{mg}$ of four formulations of phenytoin sodium in healthy, normal Indian volunteers. Ther Drug Monit. 2003;25(2):215-20.

Reason for exclusion: No intervention of interest

Gomez-Marin O, Prineas RJ, Sinaiko AR. The Sodium-Potassium Blood Pressure Trial in Children. Design, recruitment, and randomization: the children and adolescent blood pressure program. Controlled Clin Trials. 1991;12(3):408-23.

Reason for exclusion: Study on paediatrics

Gomi T, Shibuya Y, Sakurai J, Hirawa N, Hasegawa K, Ikeda T. Strict dietary sodium reduction worsens insulin sensitivity by increasing sympathetic nervous activity in patients with primary hypertension. Am J Hypertens. 1998;11(9):1048-55.

Reason for exclusion: Studies on hypertensives; Study duration less than 4 weeks

Granero R, Linfa-Homes G, Isaacura-Lopez C, Goyo A, Flores-Finizola A, Sira A. [Clinical trial withsodium fluvastatin in patients with hypercholesterolemia associated with mild and moderate essential arterial hypertension]. Investigacion clinica. 1997;38(2):63-72.

Reason for exclusion: No Sodium intervention; Treated with statins

Grey A, Braatvedt G, Holdaway I. Moderate dietary salt restriction does not alter insulin resistance or serum lipids in normal men. Am J Hypertens. 1996;9(4 Pt 1):317-22.

Reason for exclusion: Study duration less than 4 weeks

Grobbee DE, Hofman A, Roelandt JT, Boomsma F, Schalekamp MA, Valkenburg HA. Sodium restriction and potassium supplementation in young people with mildly elevated blood pressure. J Hypertens. 1987;5(1):115-9.

Reason for exclusion: Studies on children and adolescents

China Salt Substitute Study Collaborative Group. Salt substitution: a low-cost strategy for blood pressure control among rural Chinese. A randomized, controlled trial. J Hypertens. 2007;25(10):2011-8.

Reason for exclusion: Recruited above $140 \mathrm{mmHg}$ (mean 159mmHg)

He FJ, Markandu ND, MacGregor GA. Importance of the renin system for determining blood pressure fall with acute salt restriction in hypertensive and normotensive whites. Hypertension. 
2001;38(3):321-5.

Reason for exclusion: Study duration less than 4 weeks

Heagerty AM, Alton SM, el-Ashry A, Bing RF, Thurston H, Swales JD. Effects of changes in sodium balance on leucocyte sodium transport: qualitative differences in normotensive offspring of hypertensives and matched controls. J Hypertens. 1986;4(3):333-7.

Reason for exclusion: No intervention of interest

Heagerty AM, Ollerenshaw JD, Robertson DI, Bing RF, Swales JD. Influence of dietary linoleic acid on leucocyte sodium transport and blood pressure. BMJ. 1986;293(6542):295-7.

Reason for exclusion: Study duration less than 4 weeks

Hodgson JM, Puddey IB, Beilin LJ, Mori TA, Burke V, Croft KD, et al. Effects of isoflavonoids on blood pressure in subjects with high-normal ambulatory blood pressure levels: a randomized controlled trial. Am J Hypertens. 1999;12(1 Pt 1):47-53.

Reason for exclusion: No intervention of interest

Hofman A, Hazebroek A, Valkenburg HA. A randomized trial of sodium intake and blood pressure in newborn infants. JAMA. 1983;250(3):370-3.

Reason for exclusion: Study on infants

Hu G, Tian H. A comparison of dietary and non-dietary factors of hypertension and normal blood pressure in a Chinese population. J Hum Hypertens. 2001;15(7):487-93.

Reason for exclusion: Not an RCT (Cross sectional)

Huledal G, Jonzon B, Malmenas M, Hedman A, Andersson LI, Odlind B, et al. Renal effects of the cyclooxygenase-inhibiting nitric oxide donator AZD3582 compared with rofecoxib and naproxen during normal and low sodium intake. Clin Pharmacol Ther. 2005;77(5):437-50. Reason for exclusion: Blood pressure not measured

Hunt PJ, Espiner EA, Richards AM, Yandle TG, Frampton C, Nicholls MG. Interactions of atrial and brain natriuretic peptides at pathophysiological levels in normal men. Am J Physiol. 1995;269(6):R1397-403.

Reason for exclusion: No Sodium intervention; ANP infused in subjects

Hypertension Prevention Trial Research Group. The Hypertension Prevention Trial: three-year effects of dietary changes on blood pressure. Arch Internal Med. 1990;150(1):153-62.

Reason for exclusion: $5 \%$ subjects baseline SBP>140mmHg.

Ishimitsu T, Nishikimi T, Matsuoka H, Kangawa K, Kitamura K, Minami J, et al. Behaviour of adrenomedullin during acute and chronic salt loading in normotensive and hypertensive subjects. Clin Sci. 1996;91(3):293-8.

Reason for exclusion: Study duration less than 4 weeks

Jablonski KL, Fedorova OV, Racine ML, Geolfos CJ, Gates PE, Chonchol M, et al. Dietary sodium restriction and association with urinary marinobufagenin, blood pressure, and aortic stiffness. CJASN. 2013;8(11):1952-9.

Reason for exclusion: Recruited above $140 \mathrm{mmHg}(<159 \mathrm{mmHg})$

Jablonski KL, Racine ML, Geolfos CJ, Gates PE, Chonchol M, McQueen MB, et al. Dietary sodium restriction reverses vascular endothelial dysfunction in middle-aged/older adults with moderately elevated systolic blood pressure. J Am Coll Cardiol. 2013;61(3):335-43.

Reason for exclusion: Recruited above $140 \mathrm{mmHg}$

Jeffery RW, Pirie PL, Elmer PJ, Bjornson-Benson WM, Mullenbach VA, Kurth CL, et al. Low-sodium, high-potassium diet: feasibility and acceptability in a normotensive population. Am J Public Health. 1984;74(5):492-4.

Reason for exclusion: Pilot study; no blood pressure results 
Jern S, Wall U, Bergbrant A, Selin-Sjogren L, Jern C. Endothelium-dependent vasodilation and tissuetype plasminogen activator release in borderline hypertension. Arterioscler Thromb Vasc Biol. 1997;17(12):3376-83.

Reason for exclusion: No Sodium intervention; Studies on hypertensives

Johnson AG, Nguyen TV, Davis D. Blood pressure is linked to salt intake and modulated by the angiotensinogen gene in normotensive and hypertensive elderly subjects. J Hypertens. 2001;19(6):1053-60.

Reason for exclusion: Recruited above $140 \mathrm{mmHg}(<160 \mathrm{mmHg})$

Kammerer-Doak DN, Rogers RG, Johnson Maybach J, Traynor Mickelson M. Vasopressin as an etiologic factor for infection in gynecologic surgery: a randomized double-blind placebocontrolled trial. Am J Obstet Gynecol. 2001;185(6):1344-7.

Reason for exclusion: No intervention of interest

Kennon B, Ingram MC, Friel EC, Anderson NH, MacKenzie SM, Davies E, et al. Aldosterone synthase gene variation and adrenocortical response to sodium status, angiotensin II and ACTH in normal male subjects. Clin Endocrinol. 2004;61(2):174-81.

Reason for exclusion: No intervention of interest

Khaw KT, Thom S. Randomised double-blind cross-over trial of potassium on blood-pressure in normal subjects. Lancet. 1982;2(8308):1127-9.

Reason for exclusion: No sodium intervention; potassium intervention only

Kingwell BA, Jennings GL. Effects of walking and other exercise programs upon blood pressure in normal subjects. MJA. 1993;158(4):234-8.

Reason for exclusion: No intervention of interest

Kiowski W, Linder L, Kleinbloesem C, van Brummelen P, Buhler FR. Blood pressure control by the renin-angiotensin system in normotensive subjects. Assessment by angiotensin converting enzyme and renin inhibition. Circulation. 1992;85(1):1-8.

Reason for exclusion: No intervention of interest

Kisioglu AN, Aslan B, Ozturk M, Aykut M, Ilhan I. Improving control of high blood pressure among middle-aged Turkish women of low socio-economic status through public health training. Croat Med J. 2004;45(4):477-82.

Reason for exclusion: Normotension defined $>140 \mathrm{mmHg}$

Klein $\mathrm{H}$, Abassi Z, Keiser HR. Effects of angiotensin II and phenylephrine on urinary endothelin in normal female volunteers. Metabolism. 1995;44(1):115-8.

Reason for exclusion: No intervention of interest

Knuist M, Bonsel GJ, Zondervan HA, Treffers PE. Low sodium diet and pregnancy-induced hypertension: a multi-centre randomised controlled trial. Brit J Obstet Gynaec. 1998;105(4):430-4.

Reason for exclusion: Study on pregnant women; only diastolic inclusion

Konishi Y, Okada N, Okamura M, Morikawa T, Okumura M, Yoshioka K, et al. Sodium sensitivity of blood pressure appearing before hypertension and related to histological damage in immunoglobulin a nephropathy. Hypertension. 2001;38(1):81-5.

Reason for exclusion: Participants with renal deficiency

Kostis JB, Wilson AC, Hooper WC, Harrison KW, Philipp CS, Appel LJ, et al. Association of angiotensin-converting enzyme DD genotype with blood pressure sensitivity to weight loss. Am Heart J. 2002;144(4):625-9.

Reason for exclusion: Studies on hypertensives

Kreutz R, Kruse HJ, Overlack A, Stumpe KO, Kolloch RE. Effects of sympathetic inhibition on blood pressure and renal responses to central hypervolaemia in normal humans. Acta physiologica 
Scandinavica. 1996;156(1):1-7.

Reason for exclusion: No intervention of interest

Krishna GG, Miller E, Kapoor S. Increased blood pressure during potassium depletion in normotensive men. N Eng J Med. 1989;320(18):1177-82.

Reason for exclusion: No intervention of interest

Kuroda S, Uzu T, Fujii T, Nishimura M, Nakamura S, Inenaga T, et al. Role of insulin resistance in the genesis of sodium sensitivity in essential hypertension. J Hum Hypertens. 1999;13(4):257-2. Reason for exclusion: Study duration less than 4 weeks; Studies on hypertensives

Kweon TD, Kim SH, Oh YJ, Shim JK, Hong YW, Kwak YL. Topical lidocaine effectively reduced the increase of systolic blood pressure after side-clamping of the aorta in off-pump cardiac surgery. Acta Anaesthesiologica Scandinavica. 2006;50(10):1218-22.

Reason for exclusion: Study on participants post-surgery

Laffer CL, Elijovich F. Essential hypertension of Caribbean Hispanics: sodium, renin, and response to therapy. J Clin Hypertens. 2002;4(4):266-73.

Reason for exclusion: Recruited above $140 \mathrm{mmHg}$

Lainchbury JG, Troughton RW, Lewis LK, Yandle TG, Richards AM, Nicholls MG. Hemodynamic, hormonal, and renal effects of short-term adrenomedullin infusion in healthy volunteers. The J Clin Endocrinol Metab. 2000;85(3):1016-20.

Reason for exclusion: Study duration less than 4 weeks

Langrish JP, Unosson J, Bosson J, Barath S, Muala A, Blackwell S, et al. Altered nitric oxide bioavailability contributes to diesel exhaust inhalation-induced cardiovascular dysfunction in man. JAHA. 2013;2(1):e004309.

Reason for exclusion: No intervention of interest

Larson A, Witman MA, Guo Y, Ives S, Richardson RS, Bruno RS, et al. Acute, quercetin-induced reductions in blood pressure in hypertensive individuals are not secondary to lower plasma angiotensin-converting enzyme activity or endothelin-1: nitric oxide. Nutr Res.

2012;32(8):557-64.

Reason for exclusion: Study duration less than 4 weeks

Larson C, Vaidya A, Sun B, Williams JS. Influence of dietary sodium modulation on electrocardiographic voltage criteria for left ventricular hypertrophy in normotensive individuals. J Invest Med. 2012;60(1):39-43.

Reason for exclusion: Participants treated with anti-hypertensives

Lasser VI, Raczynski JM, Stevens VJ, Mattfeldt-Beman MK, Kumanyika S, Evans M, et al. Trials of Hypertension Prevention, phase II. Structure and content of the weight loss and dietary sodium reduction interventions. Trials of Hypertension Prevention (TOHP) Collaborative Research Group. Ann Epidemiol. 1995;5(2):156-64.

Reason for exclusion: Study report of TOHP II

Law MR, Frost CD, Wald NJ. By how much does dietary salt reduction lower blood pressure? III-Analysis of data from trials of salt reduction. BMJ (Clinical research ed). 1991;302(6780):81924.

Reason for exclusion: Not an RCT (Review)

Lawton WJ, Sinkey CA, Fitz AE, Mark AL. Dietary salt produces abnormal renal vasoconstrictor responses to upright posture in borderline hypertensive subjects. Hypertension. 1988;11(6 Pt 1):529-36.

Reason for exclusion: Study duration less than 4 weeks

Lee CY, Chen HH, Lisy O, Swan S, Cannon C, Lieu HD, et al. Pharmacodynamics of a novel designer natriuretic peptide, CD-NP, in a first-in-human clinical trial in healthy subjects. 
Journal of clinical pharmacology. 2009;49(6):668-73.

Reason for exclusion: Wrong style intervention; drug infusions

Lennon-Edwards, S., Ramick, M. G., Matthews, E. L., Brian, M. S., Farquhar, W. B., \& Edwards, D. G. Salt loading has a more deleterious effect on flow-mediated dilation in salt-resistant men than women. Nutr, Metab and Cardiovasc, 2014;24(9):990-995.

Reason for exclusion: Study duration less than 4 weeks

Li N, Prescott J, Wu Y, Barzi F, Yu X, Zhao L, et al. The effects of a reduced-sodium, high-potassium salt substitute on food taste and acceptability in rural northern China. Brit J Nutr. 2009;101(7):1088-93.

Reason for exclusion: Not RCT; Studies on hypertensives

Light RW, Peng MJ, Stansbury DW, Sassoon CS, Despars JA, Mahutte CK. Effects of sodium bicarbonate administration on the exercise tolerance of normal subjects breathing through dead space. Chest. 1999;115(1):102-8.

Reason for exclusion: Not intervention of interest

Lijnen P, Petrov V. Dietary calcium, blood pressure and cell membrane cation transport systems in males. J Hypertens. 1995;13(8):875-82.

Reason for exclusion: Not intervention of interest

Lind L, Lithell H, Pollare T, Ljunghall S. Blood pressure response during long-term treatment with magnesium is dependent on magnesium status. A double-blind, placebo-controlled study in essential hypertension and in subjects with high-normal blood pressure. Am J Hypertens. 1991;4(8):674-9.

Reason for exclusion: Not intervention of interest

Little P, Girling G, Hasler A, Trafford A. A controlled trial of a low sodium, low fat, high fibre diet in treated hypertensive patients: effect on antihypertensive drug requirement in clinical practice. J Hum Hypertens. 1991;5(3):175-81.

Reason for exclusion: Studies on hypertensives

Locatelli F, Andrulli S, Di Filippo S, Pozzoli U, Tetta C. Effect of sodium pool changes on blood pressure in patients undergoing PFD: design of a prospective randomized multicenter trial. J Nephrol. 2001;14(3):157-61.

Reason for exclusion: Participants with renal deficiency

Lucas SJ, Tzeng YC, Galvin SD, Thomas KN, Ogoh S, Ainslie PN. Influence of changes in blood pressure on cerebral perfusion and oxygenation. Hypertension. 2010;55(3):698-705.

Reason for exclusion: Not intervention of interest

Luft FC, Zemel MB, Sowers JA, Fineberg NS, Weinberger MH. Sodium bicarbonate and sodium chloride: effects on blood pressure and electrolyte homeostasis in normal and hypertensive man. J Hypertens. 1990;8(7):663-70.

Reason for exclusion: Study duration less than 4 weeks

Luther, J. M., Byrne, L. M., Yu, C., Wang, T. J., \& Brown, N. J. Dietary sodium restriction decreases insulin secretion without affecting insulin sensitivity in humans. J Clin Endocrinol Metab. 2014;99(10):E1895-1902.

Reason for exclusion: Concomitant intervention

Maclver DH, McNally PG, Ollerenshaw JD, Sheldon TA, Heagerty AM. The effect of short chain fatty acid supplementation on membrane electrolyte transport and blood pressure. J Hum Hypertens. 1990;4(5):485-90.

Reason for exclusion: Not intervention of interest 
Makela P, Vahlberg T, Kantola I, Vesalainen R, Jula A. The effects of a 6-month sodium restriction on cardiac autonomic function in patients with mild to moderate essential hypertension. Am J Hypertens. 2008;21(11):1183-7.

Reason for exclusion: Studies on hypertensives

McCarron DA. The dietary guideline for sodium: should we shake it up? Yes! Am J Clin Nutr. 2000;71(5):1013-9.

Reason for exclusion: Not an RCT (Viewpoint)

McCarron DA, Morris CD. Blood pressure response to oral calcium in persons with mild to moderate hypertension. A randomized, double-blind, placebo-controlled, crossover trial. Ann Intern Med. 1985;103(6 Pt 1):825-31.

Reason for exclusion: Not intervention of interest

McDonald AM, Dyer AR, Liu K, Stamler R, Gosch FC, Grimm R, et al. Sodium, lithiumcountertransport and blood pressure control by nutritional intervention in 'mild' hypertension. J Hypertens. 1988;6(4):283-91.

Reason for exclusion: Studies on hypertensives

McDonald AM, Liao YL, Trevisan M, Dyer A, Gosch FC, Stamler R, et al. Sodium-lithium countertransport and systolic blood pressure response to exercise. J Hypertens. 1990;8(2):129-37.

Reason for exclusion: Not intervention of interest

Millar JA, Isles CG, Lever AF. Blood pressure, 'white-coat' pressor responses and cardiovascular risk in placebo-group patients of the MRC Mild Hypertension trial. J Hypertens. 1995;13(2):17583.

Reason for exclusion: Studies on hypertensives

Miller SB, Friese M, Sita A. Parental history of hypertension, sodium loading, and cardiovascular response to stress. Psychosom Med. 1995;57(4):381-9.

Reason for exclusion: Study duration less than 4 weeks

Mills PJ, Dimsdale JE, Ziegler MG, Hauger RL, Nelesen RA, Brown MR. Sympathetic alterations after sodium restriction and short-term captopril administration. J Am Coll Cardiol. 1993;21(1):17781.

Reason for exclusion: Studies on hypertensives

Miura K, Myogadani H, Kadoya Y, Hayashi M, Motoya M, Kuzumaki M, et al. Effectiveness of lifestyle modification programs for control of blood pressure: a non-randomized controlled trial in Komatsu, Japan. Japanese Journal of Public Health. 2006;53(8):533-42.

Reason for exclusion: Recruited above $140 \mathrm{mmHg}$

Morgan T, Myers J, Teow BH. The role of sodium and potassium in the control of blood pressure. Aust N Z J Med. 1984;14(4):458-62.

Reason for exclusion: Study duration less than 4 weeks

Moulin B, Fillastre JP, Godin M, Coquerel A, Decoopman E. Renal hemodynamics and sodium excretion after acute and chronic administration of cicletanine in normotensive and hypertensive subjects. J Cardiovasc Pharmacol. 1995;25(2):292-9.

Reason for exclusion: Participants treated with anti-hypertensives (diuretics)

Moutquin J-M, Garner PR, Burrows RF, Rey E, Helewa ME, Lange IR, et al. Report of the Canadian Hypertension Society Consensus Conference: 2. Nonpharmacologic management and prevention of hypertensive disorders in pregnancy. Can Med Assoc J. 1997;157(7):907-19.

Reason for exclusion: Not an RCT (Consensus report) 
Mtabaji JP, Nara Y, Yamori Y. The cardiac study in Tanzania: salt intake in the causation and treatment of hypertension. J Hum Hypertens. 1990;4(2):80-1.

Reason for exclusion: Study duration less than 4 weeks

Myers JB, Morgan TO. Effect of alteration in sodium chloride intake on blood pressure of normotensive subjects. J Cardiovasc Pharmacol. 1984;6(Suppl 1):S204-9.

Reason for exclusion: Study duration less than 4 weeks

Nestel PJ, Clifton PM, Noakes M, McArthur R, Howe PR. Enhanced blood pressure response to dietary salt in elderly women, especially those with small waist: hip ratio. J Hypertens. 1993;11(12):1387-94.

Reason for exclusion: No information on inclusion SBP (authors could not confirm)

Nielsen OM, Engell HC. Effects of maintaining normal plasma colloid osmotic pressure on renal function and excretion of sodium and water after major surgery. A randomized study. Danish Medical Bulletin. 1985;32(3):182-5.

Reason for exclusion: Participants with renal deficiency

Nowson C, Morgan T. Effect of calcium carbonate on blood pressure in normotensive and hypertensive people. Hypertension. 1989;13(6 Pt 1):630-9.

Reason for exclusion: Not intervention of interest

Nowson CA, Wattanapenpaiboon N, Pachett A. Low-sodium Dietary Approaches to Stop Hypertension-type diet including lean red meat lowers blood pressure in postmenopausal women. Nutr Res. 2009;29(1):8-18.

Reason for exclusion: Recruited above $140 \mathrm{mmHg}(<160 \mathrm{mmHg})$

Nowson CA, Worsley A, Margerison C, Jorna MK, Frame AG, Torres SJ, et al. Blood pressure response to dietary modifications in free-living individuals. J Nutr. 2004;134(9):2322-9. Reason for exclusion: No SBP cut off for healthy free living individuals.

Olsen NV, Olsen MH, Bonde J, Kanstrup IL, Plum I, Strandgaard S, et al. Dopamine natriuresis in salt-repleted, water-loaded humans: a dose-response study. Brit J Clin Pharmacol. 1997;43(5):509-20.

Reason for exclusion: Wrong style sodium intervention; Drugs used

Overlack A, Ruppert M, Kolloch R, Gobel B, Kraft K, Diehl J, et al. Divergent hemodynamic and hormonal responses to varying salt intake in normotensive subjects. Hypertension. 1993;22(3):331-8.

Reason for exclusion: Study duration less than 4 weeks

Pagano E, Siani A, Pauciullo P, Lirato C, lacone R, Sacchi A, et al. Effect of dietary versus pharmacological correction of hypertriglyceridemia on red blood cell membrane sodium/lithium countertransport activity. Life Sciences. 1997;60(26):2389-97

Reason for exclusion: Recruited above $140 \mathrm{mmHg}(<160 \mathrm{mmHg})$

Palmer RM, Osterweil D, Loon-Lustig G, Stern N. The effect of dietary salt ingestion on blood pressure of old-old subjects. A double-blind, placebo-controlled, crossover trial. J Ams Geriatr Soc. 1989;37(10):931-6.

Reason for exclusion: Recruited above $140 \mathrm{mmHg}$

Parker M, Puddey IB, Beilin LJ, Vandongen R. Two-way factorial study of alcohol and salt restriction in treated hypertensive men. Hypertension. 1990;16(4):398-406.

Reason for exclusion: Participants all on anti-hypertensives

Paterna S, Gaspare P, Fasullo S, Sarullo FM, Di Pasquale P. Normal-sodium diet compared with lowsodium diet in compensated congestive heart failure: is sodium an old enemy or a new friend? Clin Sci. 2008;114(3):221-30.

Reason for exclusion: Studies on Heart failure patients 
Paterna S, Parrinello G, Cannizzaro S, Fasullo S, Torres D, Sarullo FM, et al. Medium term effects of different dosage of diuretic, sodium, and fluid administration on neurohormonal and clinical outcome in patients with recently compensated heart failure. Am J Cardiol. 2009;103(1):93102.

Reason for exclusion: Participants all on anti-hypertensives

Pechere-Bertschi A, Maillard M, Stalder H, Brunner HR, Burnier M. Blood pressure and renal haemodynamic response to salt during the normal menstrual cycle. Clin Sci. 2000;98(6):697702.

Reason for exclusion: Study duration less than 4 weeks

Pedersen KE, Jest P, Klitgaard NA, Rokkedal Nielsen J, Johansen T. Effect of oral salt loading on blood pressure and lymphocyte sodium metabolism in borderline hypertension. Acta medica Scandinavica Supplementum. 1986;220(S714):81-5.

Reason for exclusion: No intervention of interest

Phillips EM, Butler T, Baylis PH. Osmoregulation of vasopressin and thirst: comparison of $20 \%$ mannitol with $5 \%$ saline as osmotic stimulants in healthy man. Clin Endocrinol.

1994;41(2):207-12.

Reason for exclusion: No intervention of interest

Piccirillo G, Fimognari FL, Munizzi MR, Bucca C, Cacciafesta M, Marigliano V. Age-dependent influence on heart rate variability in salt-sensitive hypertensive subjects. J Ams Geriatr Soc. 1996;44(5):530-8.

Reason for exclusion: Study duration less than 4 weeks

Pratt JH, Eckert GJ, Newman S, Ambrosius WT. Blood pressure responses to small doses of amiloride and spironolactone in normotensive subjects. Hypertension. 2001;38(5):1124-9.

Reason for exclusion: Studies on hypertensives; anti-hypertensives

Pretorius MM, Gainer JV, Van Guilder GP, Coelho EB, Luther JM, Fong P, et al. The bradykinin type 2 receptor BE1 polymorphism and ethnicity influence systolic blood pressure and vascular resistance. Clinical Pharmacol Ther. 2008;83(1):122-9.

Reason for exclusion: No intervention of interest

Puska P, lacono JM, Nissinen A, Korhonen HJ, Vartianinen E, Pietinen P, et al. Controlled, randomised trial of the effect of dietary fat on blood pressure. Lancet. 1983;1(8314-5):1-5.

Reason for exclusion: Studies in hypertensives.

Rankin LI, Luft FC, Henry DP, Gibbs PS, Weinberger MH. Sodium intake alters the effects of norepinephrine on blood pressure. Hypertension. 1981;3(6):650-6.

Reason for exclusion: Study duration less than 4 weeks

Rebello T, Hodges RE, Smith JL. Short-term effects of various sugars on antinatriuresis and blood pressure changes in normotensive young men. Am J Clin Nutr. 1983;38(1):84-94.

Reason for exclusion: No intervention of interest

Resnick LM, Catanzaro D, Sealey JE, Laragh JH. Acute vascular effects of the angiotensin II receptor antagonist olmesartan in normal subjects: relation to the renin-aldosterone system. Am J Hypertens. 2004;17(3):203-8.

Reason for exclusion: Wrong intervention; Drugs used

Resnick LM, Lewanczuk RZ, Laragh JH, Pang PK. Parathyroid hypertensive factor-like activity in human essential hypertension: relationship to plasma renin activity and dietary salt sensitivity. J Hypertens. 1993;11(11):1235-41.

Reason for exclusion: Only Hypertensive participants received sodium intervention 
Resnick LM, Oparil S, Chait A, Haynes RB, Kris-Etherton P, Stern JS, et al. Factors affecting blood pressure responses to diet: the Vanguard study. Am J Hypertens. 2000;13(9):956-65.

Reason for exclusion: No intervention of interest

Ribstein J, Picard A, Armagnac C, Sissmann J, Mimran A. Inhibition of the acute effects of angiotensin II by the receptor antagonist irbesartan in normotensive men. J Cardiovasc Pharmacol. 2001;37(4):449-60.

Reason for exclusion: Wrong intervention; Drugs used

Richards AM, Tonolo G, Cleland JG, McIntyre GD, Leckie BJ, Dargie HJ, et al. Plasma atrial natriuretic peptide concentrations during exercise in sodium replete and deplete normal man. Clin Sci. 1987;72(2):159-64.

Reason for exclusion: Study duration less than 4 weeks

Rouse IL, Beilin LJ, Armstrong BK, Vandongen R. Blood-pressure-lowering effect of a vegetarian diet: controlled trial in normotensive subjects. Lancet. 1983;1(8314-5):5-10.

Reason for exclusion: No Sodium intervention; Study duration less than 4 weeks

Ruppert M, Diehl J, Kolloch R, Overlack A, Kraft K, Gobel B, et al. Short-term dietary sodium restriction increases serum lipids and insulin in salt-sensitive and salt-resistant normotensive adults. Klinische Wochenschrift. 1991;69(Suppl 25):51-7.

Reason for exclusion: Study duration less than 4 weeks

Ruppert M, Overlack A, Kolloch R, Kraft K, Lennarz M, Stumpe KO. Effects of severe and moderate salt restriction on serum lipids in nonobese normotensive adults. Am J Med Sci. 1994;307 (Suppl 1):S87-90.

Reason for exclusion: Study duration less than 4 weeks

Sagnella GA, Markandu ND, Buckley MG, Miller MA, Blackwood A, Singer DR, et al. Hormonal and renal responses to neutral endopeptidase inhibition in normal humans on a low and on a high sodium intake. Eur J Clin Invest. 1995;25(3):165-70.

Reason for exclusion: Wrong style intervention; drug treatment

Sagnella GA, Markandu ND, Buckley MG, Singer DR, MacGregor GA. Atrial natriuretic peptide-cyclic GMP relationships in normal humans: effects of dietary sodium intake. Clin Sci.

1993;85(1):13-7.

Reason for exclusion: Study duration less than 4 weeks

Sano J, Ohki K, Higuchi T, Aihara K, Mizuno S, Kajimoto O, et al. Effect of casein hydrolysate, prepared with protease derived from Aspergillus oryzae, on subjects with high-normal blood pressure or mild hypertension. Journal of Medicinal Food. 2005;8(4):423-30.

Reason for exclusion: Not intervetion of interest.

Santos A, Martins MJ, Guimaraes JT, Severo M, Azevedo I. Sodium-rich carbonated natural mineral water ingestion and blood pressure. Revista portuguesa de cardiologia: orgao oficial da Sociedade Portuguesa de Cardiologia = Portuguese journal of cardiology : an official journal of the Portuguese Society of Cardiology. 2010;29(2):159-72.

Reason for exclusion: Study excluded in quality analysis; intervention not controlled, and not of an high enough intensity to see any change to blood pressure

Sarkkinen ES, Kastarinen MJ, Niskanen TH, Karjalainen PH, Venalainen TM, Udani JK, et al. Feasibility and antihypertensive effect of replacing regular salt with mineral salt -rich in magnesium and potassium- in subjects with mildly elevated blood pressure. Nutrition journal. $2011 ; 10: 88$.

Reason for exclusion: Inclusion SBP>140mmHg (130-159 mmHg)

Schorr U, Beige J, Ringel J, Turan S, Kreutz R, Distler A, et al. Hpa II polymorphism of the atrial natriuretic peptide gene and the blood pressure response to salt intake in normotensive 
men. J Hypertens. 1997;15(7):715-8.

Reason for exclusion: Study duration less than 4 weeks

Schorr U, Distler A, Sharma AM. Effect of sodium chloride- and sodium bicarbonate-rich mineral water on blood pressure and metabolic parameters in elderly normotensive individuals: a randomized double-blind crossover trial. J Hypertens. 1996;14(1):131-5.

Reason for exclusion: Recruited above $140 \mathrm{mmHg}$ at baseline

Schorr U, Turan S, Distler A, Sharma AM. Relationship between ambulatory and resting blood pressure responses to dietary salt restriction in normotensive men. J Hypertens. 1997;15(8):845-9.

Reason for exclusion: Study duration less than 4 weeks

Schrader J, Luders S, Kulschewski A, Hammersen F, Plate K, Berger J, et al. Morbidity and Mortality After Stroke, Eprosartan Compared with Nitrendipine for Secondary Prevention: principal results of a prospective randomized controlled study (MOSES). Stroke. 2005;36(6):121826.

Reason for exclusion: Studies on hypertensives

Schwartz JI, Thach C, Lasseter KC, Miller J, Hreniuk D, Hilliard DA, et al. Effects of etoricoxib and comparator nonsteroidal anti-inflammatory drugs on urinary sodium excretion, blood pressure, and other renal function indicators in elderly subjects consuming a controlled sodium diet. J Clin Pharmacol. 2007;47(12):1521-31.

Reason for exclusion: Study duration less than 4 weeks

Sciarrone SE, Beilin LJ, Rouse IL, Rogers PB. A factorial study of salt restriction and a low-fat/highfibre diet in hypertensive subjects. J Hypertens. 1992;10(3):287-98.

Reason for exclusion: Recruited above $140 \mathrm{mmHg}$

Sharma AM, Cetto C, Schorr U, Spies KP, Distler A. Renal acid-base excretion in normotensive saltsensitive humans. Hypertension. 1993;22(6):884-90.

Reason for exclusion: Study duration less than 4 weeks

Sharma AM, Ruland K, Spies KP, Distler A. Salt sensitivity in young normotensive subjects is associated with a hyperinsulinemic response to oral glucose. J Hypertens. 1991;9(4):329-35. Reason for exclusion: Study duration less than 4 weeks

Sharma AM, Schattenfroh S, Kribben A, Distler A. Reliability of salt-sensitivity testing in normotensive subjects. Klinische Wochenschrift. 1989;67(12):632-4.

Reason for exclusion: Study duration less than 4 weeks

Sharma AM, Schorr U, Distler A. Insulin resistance in young salt-sensitive normotensive subjects. Hypertension. 1993;21(3):273-9.

Reason for exclusion: Study duration less than 4 weeks

Sharma AM, Schorr U, Oelkers W, Distler A. Effects of sodium salts on plasma renin activity and norepinephrine response to orthostasis in salt-sensitive normotensive subjects. Am J Hypertens. 1993;6(9):780-5.

Reason for exclusion: Study duration less than 4 weeks

Siani A, Strazzullo P, Russo L, Guglielmi S, lacoviello L, Ferrara LA, et al. Controlled trial of long term oral potassium supplements in patients with mild hypertension. BMJ. 1987;294(6585):1453-6. Reason for exclusion: No intervention of interest

Sinaiko AR, Gomez-Marin O, Prineas RJ. Effect of low sodium diet or potassium supplementation on adolescent blood pressure. Hypertension. 1993;21(6 Pt 2):989-94.

Reason for exclusion: Study on adolescents 
Singh RB, Sharma VK, Rastogi SS, Singh NK. In patients with mild hypertension, does exercise and a gradual rather than abrupt increase in fatty acid and salt intake cause less rise in cardiovascular risk factors? Clin Nutr. 1992;11(5):309-14.

Reason for exclusion: Studies on hypertensives

Skrabal F, Aubock J, Hortnagl H. Low sodium/high potassium diet for prevention of hypertension: probable mechanisms of action. Lancet. 1981;2(8252):895-900.

Reason for exclusion: Study duration less than 4 weeks

Staessen J, Bulpitt CJ, Fagard R, Joossens JV, Lijnen P, Amery A. Salt intake and blood pressure in the general population: a controlled intervention trial in two towns. J Hypertens. 1988;6(12):965-73.

Reason for exclusion: Not an RCT (cross sectional)

Stamler J, Caggiula A, Grandits GA, Kjelsberg M, Cutler JA. Relationship to blood pressure of combinations of dietary macronutrients. Findings of the Multiple Risk Factor Intervention Trial (MRFIT). Circulation. 1996;94(10):2417-23.

Reason for exclusion: Studies on participants with diabetes

Stamler R, Grimm RH, Jr., Dyer AR, Talano JV, Prineas R, Crow R, et al. Cardiac status after four years in a trial on nutritional therapy for high blood pressure. Arch Intern Med. 1989;149(3):661-5.

Reason for exclusion: Studies on hypertensives

Stamler R, Stamler J, Grimm R, Gosch FC, Elmer P, Dyer A, et al. Nutritional therapy for high blood pressure. Final report of a four-year randomized controlled trial--the Hypertension Control Program. JAMA. 1987;257(11):1484-91.

Reason for exclusion: Participants all on anti-hypertensives, discontinued 2 months in

Straznicky NE, Howes LG, Barrington VE, Lam W, Louis WJ. Effects of dietary lipid modification on adrenoceptor-mediated cardiovascular responsiveness and baroreflex sensitivity in normotensive subjects. Blood Pressure. 1997;6(2):96-102.

Reason for exclusion: No Sodium intervention; Study duration less than 4 weeks

Straznicky NE, Louis WJ, McGrade P, Howes LG. The effects of dietary lipid modification on blood pressure, cardiovascular reactivity and sympathetic activity in man. J Hypertens. 1993;11(4):427-37.

Reason for exclusion: No Sodium intervention; Study duration less than 4 weeks

Suckling RJ, He FJ, Markandu ND, MacGregor GA. Dietary salt influences postprandial lasmasodium concentration and systolic blood pressure. Kidney Int. 2012;81(4):407-11.

Reason for exclusion: Wrong sodium type intervention (one meal)

Sudhir K, Friberg P, Meredith IT, Woods RL, Esler MD, Jennings GL. Cardiac secretion and renal clearance of atrial natriuretic peptide in normal man: effect of salt restriction. Clin Sci. 1989;77(6):605-10.

Reason for exclusion: Blood pressure not measured/reported

Svetkey LP, Simons-Morton DG, Proschan MA, Sacks FM, Conlin PR, Harsha D, et al. Effect of the dietary approaches to stop hypertension diet and reduced sodium intake on blood pressure control. J Clin Hypertens. 2004;6(7):373-81.

Reason for exclusion: Recruited above $140 \mathrm{mmHg}$

Swift PA, Markandu ND, Sagnella GA, He FJ, MacGregor GA. Modest salt reduction reduces blood pressure and urine protein excretion in black hypertensives: a randomized control trial. Hypertension. 2005;46(2):308-12.

Reason for exclusion: Recruited above $140 \mathrm{mmHg}$ 
Taddei S, Virdis A, Mattei P, Ghiadoni L, Gennari A, Fasolo CB, et al. Aging and endothelial function in normotensive subjects and patients with essential hypertension. Circulation. 1995;91(7):1981-7.

Reason for exclusion: Not intervention of interest

Tarhan F, Erbay E, Eryildirim B, Faydaci G, Kuyumcuoglu U. The effect of intravesical sodium nitroprusside on idiopathic detrusor overactivity. Urol Res. 2004;32(3):200-3.

Reason for exclusion: Not intervention of interest

Terra SG, Blum RA, Wei GC, Lew RA, Digenio AG, Rajman I, et al. Evaluation of methods for improving precision of blood pressure measurements in phase I clinical trials. J Clin Pharmacol. 2004;44(5):457-63.

Reason for exclusion: Not intervention of interest

Todd, A. S., MacGinley, R. J., Schollum, J. B., Johnson, R. J., Williams, S. M., Sutherland, W. H., Walker, R. J. Dietary salt loading impairs arterial vascular reactivity. Am J Clin Nutr. 2010;91(3):557-564.

Reason for exclusion: Studies on hypertensives

Tomita Y, Ueno M, Tsuchihashi T, Muratani H, Kobayashi K, Takishita S, et al. Chloride ion plays an important role in sodium induced volume expansion in normal humans. Am J Hypertens. 1990;3(6 Pt 1):485-7.

Reason for exclusion: Study duration less than 4 weeks

Townsend MS, Fulgoni VL, 3rd, Stern JS, Adu-Afarwuah S, McCarron DA. Low mineral intake is associated with high systolic blood pressure in the Third and Fourth National Health and Nutrition Examination Surveys: could we all be right? Am J Hypertens. 2005;18(2 Pt 1):261-9. Reason for exclusion: Not RCT

Townsend RR, Kapoor S, McFadden CB. Salt intake and insulin sensitivity in healthy human volunteers. Clin Sci. 2007;113(3):141-8.

Reason for exclusion: Study duration less than 4 weeks

Tzemos N, Lim PO, Wong S, Struthers AD, MacDonald TM. Adverse cardiovascular effects of acute salt loading in young normotensive individuals. Hypertension. 2008;51(6):1525-30.

Reason for exclusion: Study duration less than 4 weeks

Udelson JE, Bilsker M, Hauptman PJ, Sequeira R, Thomas I, O'Brien T, et al. A multicenter, randomized, double-blind, placebo-controlled study of tolvaptan monotherapy compared to furosemide and the combination of tolvaptan and furosemide in patients with heart failure and systolic dysfunction. J Card Fail. 2011;17(12):973-81.

Reason for exclusion: Not intervention of interest

Uusitupa M, Korhonen M, Litmanen H, Niskanen L, Vaisanen S, Rauramaa R. Effects of moderate salt restriction alone and in combination with cilazapril on office and ambulatory blood pressure. J Hum Hypertens. 1996;10(5):319-26.

Reason for exclusion: Recruited above $140 \mathrm{mmHg}$

van de Wal RM, Gansevoort RT, van der Harst P, Boomsma F, Thijs Plokker HW, van Veldhuisen DJ, et al. Predictors of angiotensin-converting enzyme inhibitor-induced reduction of urinary albumin excretion in nondiabetic patients. Hypertension. 2006;48(5):870-6.

Reason for exclusion: No Sodium intervention; Recruited above $140 \mathrm{mmHg}$

van Paassen $P$, de Zeeuw D, Navis G, de Jong PE. Does the renin-angiotensin system determine the renal and systemic hemodynamic response to sodium in patients with essential hypertension? Hypertension. 1996;27(2):202-8.

Reason for exclusion: Study duration less than 4 weeks ( 3 weeks) 
Vierhapper $\mathrm{H}$, WaldhausI W, Nowotny P. Effect of indomethacin upon angiotensin-induced changes in blood pressure and plasma aldosterone in normal man. Eur J Clin Invest. 1981;11 (2 Suppl 1):85-9.

Reason for exclusion: Not intervention of interest

Visser FW, Boonstra AH, Titia Lely A, Boomsma F, Navis G. Renal response to angiotensin II is blunted in sodium-sensitive normotensive men. Am J Hypertens. 2008;21(3):323-8.

Reason for exclusion: Study duration less than 4 weeks

Volek JS, Mazzetti SA, Farquhar WB, Barnes BR, Gomez AL, Kraemer WJ. Physiological responses to short-term exercise in the heat after creatine loading. Med Sci Sports Exerc. 2001;33(7):1101-8.

Reason for exclusion: No Sodium intervention; Study duration less than 4 weeks

Wan L, Bellomo R, May CN. A comparison of $4 \%$ succinylated gelatin solution versus normal saline in stable normovolaemic sheep: global haemodynamic, regional blood flow and oxygen delivery effects. Anaesth Intensive Care. 2007;35(6):924-31:85-9.

Reason for exclusion: Not intervention of interest

Wan L, Bellomo R, May CN. The effects of normal and hypertonic saline on regional blood flow and oxygen delivery. Anesth Analg. 2007;105(1):141-7.

Reason for exclusion: Studies in sheep (non-human study)

Wedler B, Brier ME, Wiersbitzky M, Gruska S, Wolf E, Kallwellis R, et al. Sodium kinetics in saltsensitive and salt-resistant normotensive and hypertensive subjects. J Hypertens. 1992;10(7):663-9.

Reason for exclusion: No Sodium intervention; Study duration less than 4 weeks

Weinberger MH, Wagner UL, Fineberg NS. The blood pressure effects of calcium supplementation in humans of known sodium responsiveness. Am J Hypertens. 1993;6(9):799-805.

Reason for exclusion: No Sodium intervention; calcium treatment

Weir MR, Dengel DR, Behrens MT, Goldberg AP. Salt-induced increases in systolic blood pressure affect renal hemodynamics and proteinuria. Hypertension. 1995;25(6):1339-44.

Reason for exclusion: Study duration less than 4 weeks

Wenner MM, Edwards DG, Ray CA, Rose WC, Gardner TJ, Stillabower M, et al. Celecoxib does not alter cardiovascular and renal function during dietary salt loading. Clin Exp Pharmacol Physiol. 2011;38(8):543-9.

Reason for exclusion: Wrong intervention; drug infusions

Whelton PK, Appel L, Charleston J, Dalcin AT, Ewart C, Fried L, et al. The effects of nonpharmacologic interventions on blood pressure of persons with high normal levels: results of the Trials of Hypertension Prevention, phase I. JAMA. 1992;267(9):1213-20.

Reason for exclusion: Included $5 \%$ participants $>140 \mathrm{mmHg}$ at baseline

Whelton PK, Hebert PR, Cutler J, Applegate WB, Eberlein KA, Klag MJ, et al. Baseline characteristics of participants in phase I of the Trials of Hypertension Prevention. Ann Epidemiol. 1992;2(3):295-310.

Reason for exclusion: Not RCT (report from TOHP I)

Whelton PK, Kumanyika SK, Cook NR, Cutler JA, Borhani NO, Hennekens CH, et al. Efficacy of nonpharmacologic interventions in adults with high-normal blood pressure: results from phase 1 of the Trials of Hypertension Prevention. Trials of Hypertension Prevention Collaborative Research Group. Am J Clin Nutr. 1997;65(2 Suppl):652S-60S.

Reason for exclusion: Not RCT (report from TOHP I) 
White WB, Derosier FJ, Thompson AH, Adams BE, Goodman DK. Evaluation of the migraine treatment sumatriptan/naproxen sodium on blood pressure following long-term administration. J Clin Hypertens 2011;13(12):910-6.

Reason for exclusion: Wrong intervention; on medications

Williamson PM, Buddle ML, Brown MA, Whitworth JA. Ambulatory blood pressure monitoring (ABPM) in the normal menstrual cycle and in women using oral contraceptives. Comparison with conventional blood pressure measurement. Am J Hypertens. 1996;9(10 Pt 1):953-8. Reason for exclusion: No Sodium intervention; women using OCP

Wilson DK, Sica DA, Miller SB. Effects of potassium on blood pressure in salt-sensitive and saltresistant black adolescents. Hypertension. 1999;34(2):181-6.

Reason for exclusion: Studies in adolescents; Study duration less than 4 weeks

Wray DW, Nishiyama SK, Harris RA, Zhao J, McDaniel J, Fjeldstad AS, et al. Acute reversal of endothelial dysfunction in the elderly after antioxidant consumption. Hypertension. 2012;59(4):818-24.

Reason for exclusion: Not intervention of interest

Wright JT, Jr., Rahman M, Scarpa A, Fatholahi M, Griffin V, Jean-Baptiste R, et al. Determinants of salt sensitivity in black and white normotensive and hypertensive women. Hypertension. 2003;42(6):1087-92.

Reason for exclusion: Study duration less than 4 weeks

Writing Group of the PREMIER Collaborative Research Group. Effects of comprehensive lifestyle modification on blood pressure control. JAMA. 2003;289(16):2083.

Reason for exclusion:Statisitical data could not be provided by authors regarding nonhypertensive subgroup.

Yazici M, Kaya A, Kaya Y, Albayrak S, Cinemre H, Ozhan H. Lifestyle modification decreases the mean platelet volume in prehypertensive patients. Platelets. 2009;20(1):58-63.

Reason for exclusion: No compliance measure; no control group; Not RCT

Zabeeda D, Medalion B, Jackobshvilli S, Ezra S, Schachner A, Cohen AJ. Comparison of systemic vasodilators: effects on flow in internal mammary and radial arteries. Ann Thorac Surg. 2001;71(1):138-41.

Reason for exclusion: No Sodium intervention; participants undergoing surgery

Zhou B, Wang HL, Wang WL, Wu XM, Fu LY, Shi JP. Long-term effects of salt substitution on blood pressure in a rural north Chinese population. J Hum Hypertens. 2013;27(7):427-33.

Reason for exclusion: Information on SBP cut off for normotensive subpopulation could not be obtained. included participants with diabtes melittus.

Zhou, X., Liu, J.-X., Shi, R., Yang, N., Song, D.-L., Pang, W., \& Li, Y.-M. Compound ion salt, a novel low-sodium salt substitute: from animal study to community-based population trial. Am J Hypertens,2009;22(9):934-942.

Reason for exclusion: Concomitant intervention (Potassium supplement) 
Appendix VI: Results of sensitivity analysis using alternative levels of correlation coefficient ( $\mathrm{r}=0.2$, and 0.8 ) associated with flaxseed meta- analysis of the effect of salt modification on blood pressure and pulse wave velocity.

\begin{tabular}{|c|c|c|c|c|c|}
\hline Alternative $r$ & & $\begin{array}{l}\text { Mean difference }(95 \% \\
\mathrm{Cl}), \mathrm{mm} \mathrm{Hg}\end{array}$ & p value & $P^{2}$ & $\begin{array}{l}I^{2} \text { of main } \\
\text { analysis (with } \\
r=0.05 \text { ) }\end{array}$ \\
\hline \multirow[t]{3}{*}{0.2} & SBP & $-0.67(-1.77,0.43)$ & 0.23 & $16 \%$ & $53 \%$ \\
\hline & DBP & $-0.56(-1.19,0.07)$ & 0.08 & $0 \%$ & $0 \%$ \\
\hline & PWV & $0.85(-1.44,3.13)$ & 0.47 & $0 \%$ & $0 \%$ \\
\hline \multirow[t]{3}{*}{0.8} & SBP & $-0.38(-1.93,1.17)$ & 0.63 & $69 \%$ & $53 \%$ \\
\hline & DBP & $-0.54(-1.10,0.03)$ & 0.06 & $3 \%$ & $0 \%$ \\
\hline & PWV & $0.73(-0.75,2.21])$ & 0.33 & $30 \%$ & $0 \%$ \\
\hline
\end{tabular}

Changes in SBP, DBP, and PWV are presented as mean difference and $95 \% \mathrm{Cl}$. Heterogeneity $\left(I^{2}\right)$ is presented by $\%$. A p-value $<0.05$ was considered significant. 